\title{
Geochemistry and petrogenesis of Biabanak-Bafq mafic magmatism: Implication for the evolution of central Iranian terrane
}

\author{
Monireh Poshtkoohi ${ }^{1,2, *}$, Talat Ahmad ${ }^{1,3}$ and Ashwini Kumar Choudhary ${ }^{4}$ \\ ${ }^{1}$ Department of Geology, Centre for Advanced Studies, University of Delhi, New Delhi 110 021, India. \\ ${ }^{2}$ Department of Petrology, Geological Survey of Iran, Tehran, Iran. \\ ${ }^{3}$ Currently Vice Chancellor of University of Jamia Millia Islamia, New Delhi 110 025, India. \\ ${ }^{4}$ Institute Instrumentation Centre, Indian Institute of Technology, Roorkee 247 667, India. \\ *Corresponding author. e-mail: m_poshtkoohi@yahoo.com
}

MS received 22 May 2017; revised 15 September 2017; accepted 9 November 2017; published online 3 July 2018

Precambrian magmatism in the Biabanak-Bafq district represents an extensive sequence of mafic magmatic rocks. Major, trace and rare earth elements reveal that the low-Ti basement mafic rocks are magnesium tholeiite and low-Ti cover a mafic rock belongs to Fe-tholeiite, whereas, the high-Ti alkaline mafic rocks, as well as dolerites, show much more Fe-Ti enrichment. Primitive mantle normalized trace element patterns show a relative enrichment of LREE and LILE and depletion of HFSE, but have an equally distinct continental signature reflected by marked negative $\mathrm{Nb}, \mathrm{Sr}, \mathrm{P}$, and Ti anomalies. The composition of the intrusive rocks is consistent with fractional crystallization of olivine \pm clinopyroxene \pm plagioclase, whereas variations in the $\mathrm{Sr}$ and $\mathrm{Nd}$ isotope compositions suggest heterogeneous sources and crustal contamination. Low-Ti group samples contain a crustal signature in the form of high La/Yb, $\mathrm{Zr} / \mathrm{Nb}$, and negative $\varepsilon \mathrm{Nd}$ values. In contrast, high-Ti mafic magmatic rocks display an increase in $\mathrm{La} / \mathrm{Yb}$ with a decrease in Proterozoic alkaline rocks recognized across the central Iran. The presence of diverse mafic magmatic rocks probably reflects heterogeneous nature of sub-continental lithospheric mantle (SCLM) source. The mafic magmatism largely represents magmatic arc or rift tectonic setting. It is suggested that the SCLM sources were enriched by subduction processes and asthenospheric upwelling.

Keywords. Proterozoic; mafic magmatism; sub-continental lithosphere; asthenosphere; crust; rift; arc.

\section{Introduction}

The cratonization of Arabian-Nubian Shield (ANS) occurred transitionally from African towards Iranian plate as evidenced from the age of the Precambrian basements (Ghorbani 2013). The ANS represents juvenile crust that evolved during the Pan-African orogenic event ( 950-540 Ma) (Kröner 1985). Part of the ANS is represented by the basement rocks of central Iran in Saghand region, which has been studied by many authors (Stöcklin 1968, 1974; Nabavi 1976; Berberian and King 1981). The central Iranian terrane (CIT) is one of the continental fragments that got welded to the oceanic crust along shear zones. As one of the largest Late Proterozoic orogenic belt in the Iran, the central Iran orogenic belt is of great interest due to its long-term evolutionary history and complex tectonic magmatism. The Proterozoic geological history of the Biabanak-Bafq district 
was fundamentally related to the amalgamation and dissociation of the supercontinent Rodinia (Ghorbani 2013). Although, the general tectonic framework, the timing, and geometry of rifting, along this area are not well constrained.

The end of the Proterozoic was a period of a widespread continental breakup, before Paleozoic reassembly of the fragments in the Gondwanaland and Pangaea (Hoffman 1991). The Proterozoic rock assemblages from Chapedony, Boneh-Shurow and Posht-e-Badam complexes of central Iran consist of granitoidic gneiss, amphibolite, meta-gabbro, meta-diorite, meta-andesite, hornblendite, pyroxenite, serpentinite, which are considered to belong to island arc tectonic setting (Stöcklin et al. 1972; Haghipour 1974, 1977; Berberian and King 1981). After the establishment of the Arabian-Iranian platform at the end of Pan-African orogeny, an extension was accompanied by bimodal magmatic activity. The Late Neoproterozoic alkali-enriched Zarigan and Narigan granites in Biabak-Bafq district are equivalents of Doran granites of western Iran, which are considered equivalent to the $\sim 600$ Ma granites of Arabian Peninsula (Stöcklin et al. 1964; Schmidt et al. 1978; Sillitoe 1979). The Doran granite cuts the Proterozoic low-grade metamorphic rocks of the Kahar Formation and is covered by Early Cambrian sediments (Stöcklin 1968). The extensive 'post-orogenic' volcanic to volcaniclastic rocks including basalt, andesite and tuff, which overlie the basement rocks and are in turn overlain by Late Neoproterozoic-Early Cambrian sediments. Following Late Neoproterozoic (Pan-African) orogeny and consolidation of the basement, the Precambrian cratons of Iran, Pakistan, central Afghanistan, south-eastern Turkey and Arabia became a relatively stable continental platform with epicontinental shelf deposits. According to White and McKenzie (1989), the origin of basic volcanic magmas in the continental settings is often believed to be by decompression and partial melting of an upwelling asthenospheric mantle close to the base of the sub-continental lithospheric mantle (SCLM). Small volumes of alkaline mafic magmas can also originate within the SCLM through direct partial melting of the metasomatised lithospheric mantle as a consequence of thermal perturbations (White and McKenzie 1989). Hassanzadeh et al. (2008) and Alirezaei and Hassanzadeh (2012) determined U-Pb crystallization ages of the granites and orthogneisses and suggested that they were Late NeoproterozoicEarly Cambrian $(533 \pm 8$ to $547 \pm 3 \mathrm{Ma})$, which matches with the evolution of juvenile ANS and Peri-Gondwanan terranes. Zircon U-Pb data indicate that the Boneh-Shurow metamorphic complex is the oldest rock unit yielding ${ }^{207} \mathrm{~Pb} /{ }^{206} \mathrm{~Pb}$ age of $543 \pm 36 \mathrm{Ma}$; while some grains yielded older ages indicative of an inherited component typical for non-juvenile granitic melts or detrital inheritance (Ramezani and Tucker 2003; Verdel et al. 2007). Boneh-Shurow complex is intruded by quartzdioritic body, for which concordant analyses were obtained with the ${ }^{207} \mathrm{~Pb} /{ }^{206} \mathrm{~Pb}$ age of $547 \pm 3 \mathrm{Ma}$. For the well-known Zarigan-type leucogranites and granodiorites, a ${ }^{207} \mathrm{~Pb} /{ }^{206} \mathrm{~Pb}$ age of $533 \pm 8 \mathrm{Ma}$ was obtained with an older inherited component (Ramezani and Tucker 2003).

By integrating stratigraphic, geochronological, geochemical, and structural data of the key units, our understanding of the crustal evolution of basement and cover rocks connecting to Rodinia can be refined. The present study aims to discuss the geochemical characterization, petrogenesis and tectonic setting of the investigated orogenic and post-orogenic mafic igneous rocks. We shall use geochemical data to put constraints on the source characteristics, magma evolution, partial melting and fractional crystallization processes that govern the investigated mafic rocks from Biabanak-Bafq district in central Iran. These are of great importance to understand the evolutionary history of the central Iranian basement rocks during the PanAfrican Orogeny.

\section{Regional geological setting}

The Iranian plateau consists of several continental fragments welded together along old oceanic suture zones. The continental crust of the CIT is one of these fragments, which was metamorphosed, folded and intruded by granites during the Pan-African Orogeny (Ramezani and Tucker 2003; Nadimi 2007). In the Biabanak-Bafq district of CIT, three roughly NE trending litho-tectonic domains, from east to west, are Posht-e-Badam, Chatak, and Chapedony with faulted contacts with each other (figure 1). The basement complexes are cropped out in the Saghand region and extensively overprinted by the Pan-African orogeny and younger igneous events. Early Cambrian orogeny of the Biabank-Bafq district marks one of the fundamental lithospheric boundaries within Gondwana. This boundary belongs to Late Neoproterozoic-Early Paleozoic orogenic system that was active along 


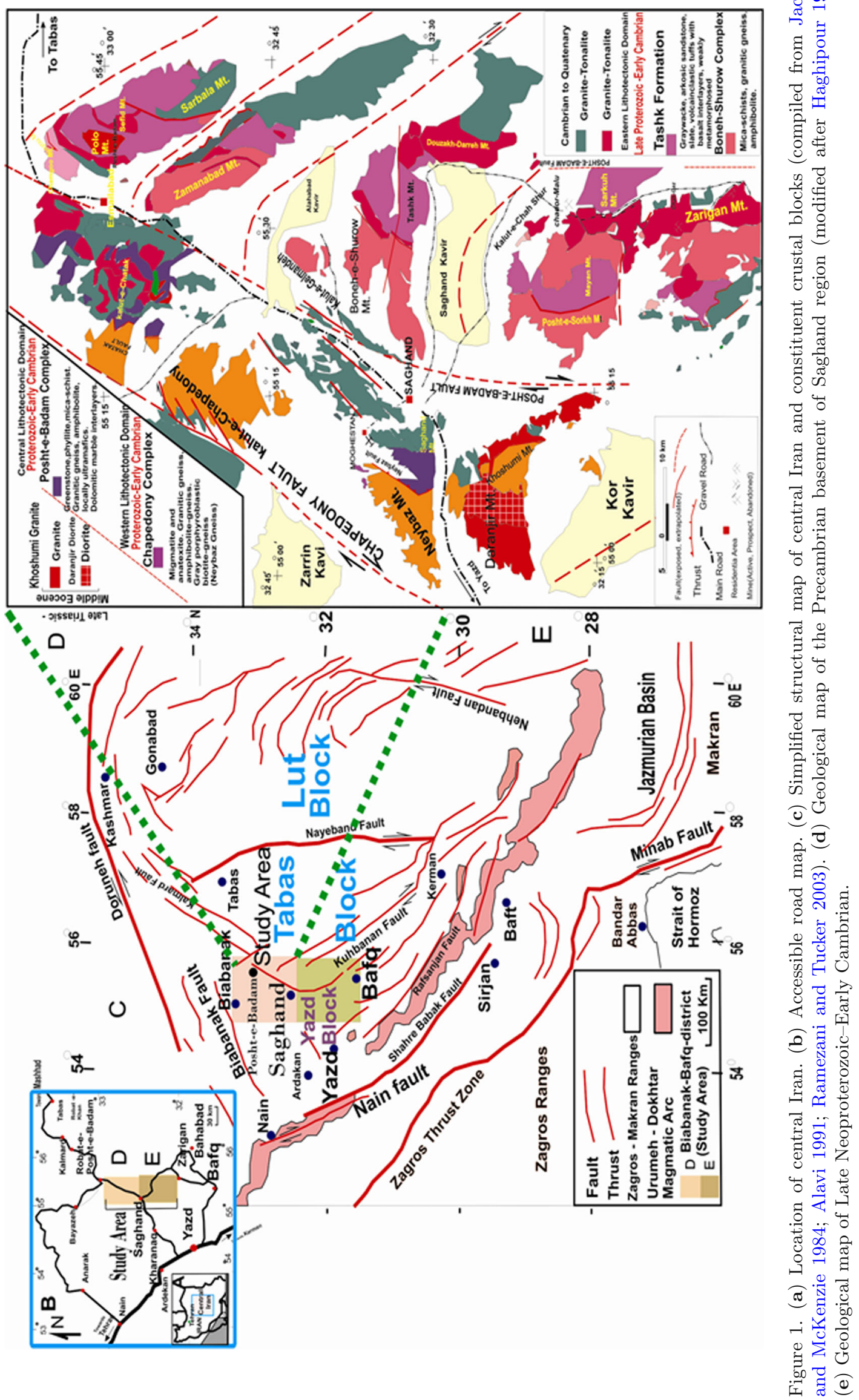




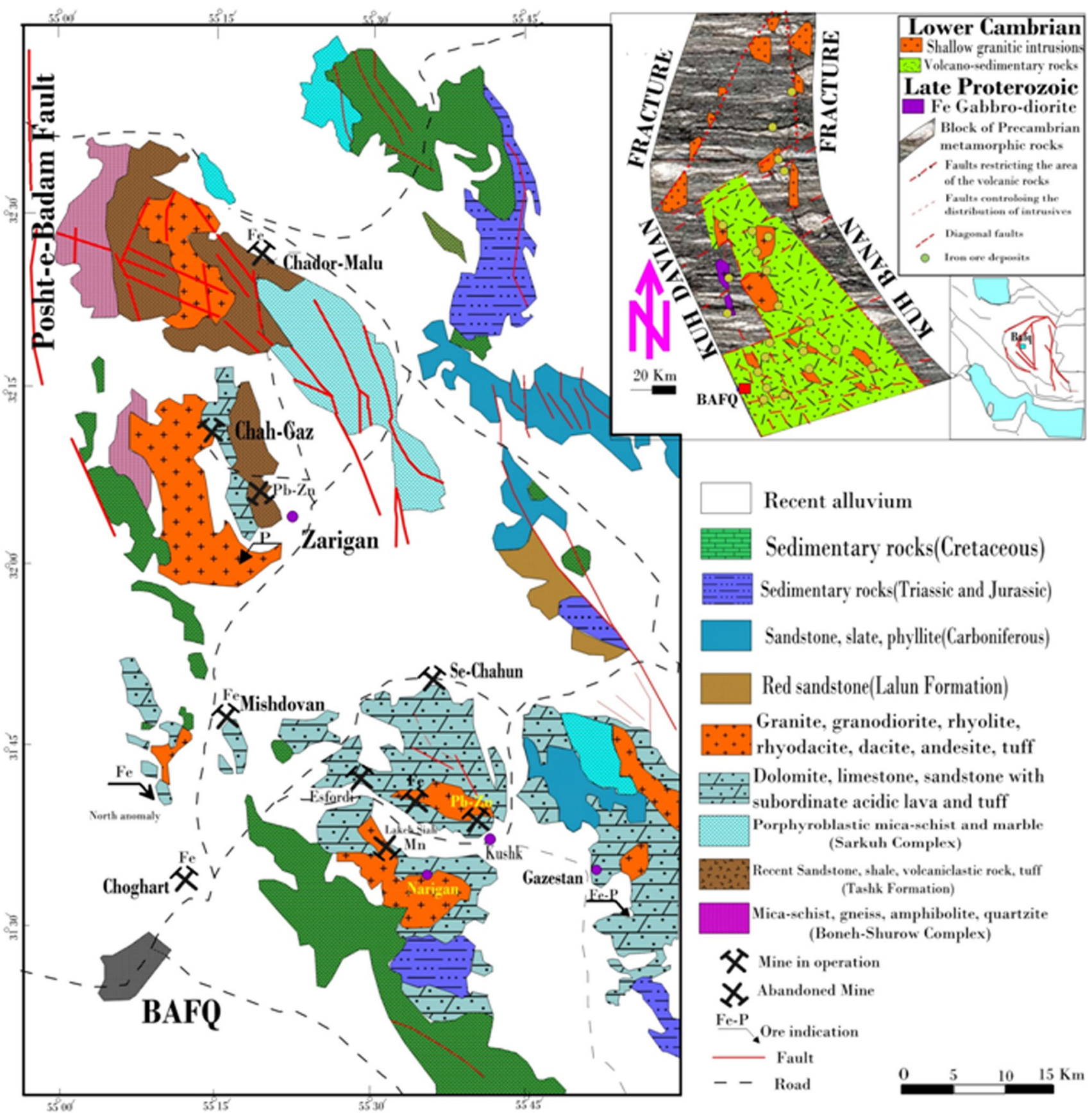

Figure 2. Geological map of Late Neoproterozoic-Early Cambrian of southeastern part of Posht-e-Badam Block, BiabanakBafq district, central Iran (modified after Haghipour 1977).

the Proto-Tethyan margin of the Gondwanaland, extending from Arabian margin to the Himalayan margin of the Indian sub-continent. The BiabanakBafq district comprises continental basement with volcano-sedimentary cover including most important iron ore resources of Iran, which is located between Bafq city in the south and Posht-e-Badam village in the north. The Posht-e-Badam Block, located in Biabanak-Bafq district, is a narrow
$\mathrm{N}-\mathrm{S}$ trending rift zone, constituting metallogenic province of Precambrian-Cambrian age, which is a part of Central Iranian Structural Zone (Stöcklin 1968) (figure 2). All metamorphic, plutonic and volcanic rocks in the study area are cut by post-orogenic mafic-felsic dykes. The Late Neoproterozoic-Early Cambrian volcanism has a predominantly felsic character (rhyolitic to rhyodacitic) with subordinate andesite-andesitic basalt, 
spilitic basalts, mafic intrusive bodies and late doleritic dyke swarms with alkaline character (figure 2). Metavolcanic rocks in this area are intercalated with quartzite and slate with marble lenses. The Late Neoproterozoic-Early Cambrian magmatism is related to an arc setting, as proposed by Ramezani and Tucker (2003) that is consistent with low-Ti samples of basement amphibolites and cover mafic rocks. The high-Ti cover mafic sequences indicate alkaline nature, considered as an extensional regime during shortly after arc tectonic settings (Samani 1988; Daliran 2002; Daliran et al. 2009, 2010).

\section{Petrography}

The samples have been collected from the basement amphibolites and cover mafic rocks from the study area. In this study, we have used the term 'amphibolites' for all varieties of basement metamorphosed mafic rocks. The cover mafic rocks are termed as gabbros, gabbro-diorites, doleritic dykes, basalts and basaltic andesites, based on their texture and mineralogy. The amphibolites are dark green to black and massive. Xenoliths of amphibolite take place within the basement gneisses, which indicate that amphibolites are probably the oldest units in this area. The composition of fresh phenocrysts of plagioclase is mostly andesinelabradorite but albitization is also observed in some samples where plagioclases have calcic cores and albitic rims. These rocks are schistose and banded with amphibole and feldspar rich layers. Brownish hornblende is the chief mafic mineral in hornblende or mala gabbros of the study area. In these rocks, hornblende makes up two-thirds of the volume, anorthite a quarter, and the rest is composed of pyroxene (which is converted to amphibole) and iron oxide. Hornblende occurs as large ophitic or hetero-granular textures enclosing the other constituents (figure 3a). Majority of cover mafic rocks have preserved igneous textures and contain pyroxene, amphibole (hornblende), feldspar (plagioclase and $\mathrm{K}$-feldspar), biotite, magnetite, titanite, rare quartz and apatite (figures $3 \mathrm{~b}-\mathrm{f}$ ). Postcrystallization and deformation can be visualized by the presence of fractured phenocrysts of feldspar and plagioclase. Rounded corners of feldspar phenocrysts indicate an event of magmatic corrosion. Plagioclase crystals are saussuritized to some extent. Actinolite and biotite retrograde reaction rims are present around pyroxenes and amphiboles.
Clinopyroxene and hornblende minerals occur as euhedral to subhedral phenocrysts, but they are often partially replaced by actinolite, chlorite, and biotite. Some of the amphiboles (hornblende) may have formed due to the alteration of augite at the late magmatic stage as suggested by the parallelism of hornblende with augite and at some places the former makes a reaction rim around augite crystals. Ophitic to sub-ophitic relationships between plagioclase and clinopyroxene phenocrysts are common (figure $3 \mathrm{f}$ ). The more mafic samples have small olivine phenocrysts, mostly pseudomorphosed by chlorite-serpentine. Other minors, accessory and secondary minerals are chlorite, serpentine, epidote, calcite, quartz, biotite, Fe-Ti oxides and titanite.

Basic volcanic rocks often show vesicles with quartz, calcite, epidote and zeolite amygdales. The fine-grained basic rocks show quenched texture in the form of variolitic laths of plagioclase feldspars (figure $3 \mathrm{~b}$ ). Joints and fractures are common and filled from quartz and epidote veins. Doleritic dykes show ophitic or sub-ophitic textures. Mineralogically, they resemble the volcanic rocks except for the presence of late crystallizing K-feldspar as an interstitial component. They have escaped the effects of albitization, and lucid phenocrysts of plagioclases are observed in the most of dyke samples. Alteration effects to some extent can be seen in the field and also through petrographic studies. The growth of secondary minerals like chlorite, epidote, biotite, and amphibole are used as parameters to understand the degree of alteration. Limited growth of these minerals at grain boundary may develop due to the interaction with late magmatic fluids and thus are considered isocheimal (Pollard et al. 1983; Taylor and Pollard 1988). Bands of quartz and feldspar grains are also present, but the bands are not continuous.

The mafic rocks reported here appear to have been affected by some extents by post magmatic alteration, metamorphism, and deformation. This alters the abundance of individual elements to some extent, particularly for samples with higher LOI (>2 wt.\%). The mafic intrusive rocks are fresh and massive with very little alteration compared to the volcanic rocks. Similarly, the dykes are less altered compared to contemporary lava volcanic rocks. In this study, mafic samples in the Biabanak-Bafq district with anomalously low $\mathrm{CaO}$ (<5 wt.\%), high LOI (>2 wt.\%), or high $\mathrm{Na}_{2} \mathrm{O}$ (2.95 wt.\%) concentrations are interpreted to be 

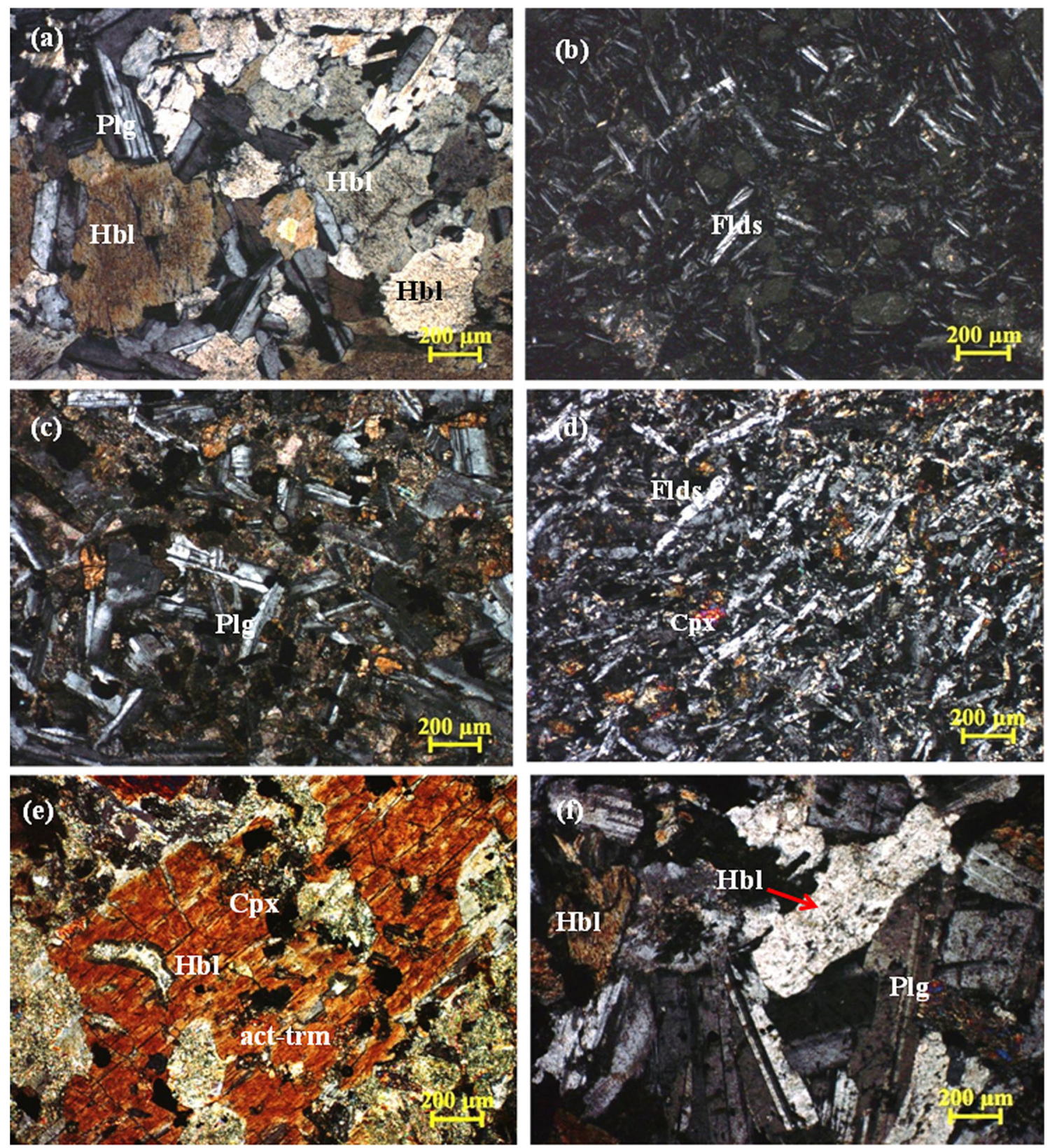

Figure 3. Photomicrographs under cross-polarized light of basement and cover basement rock samples: (a) amphibolite; (b) spilitic basalt; (c) doleritic dyke; (d) spilitic doleritic dyke; (e) hornblendite; (f) micro-monzogabbro. Abbreviations of mineral names are after White and McKenzie (1989). Act-Tr = actinolite-tremulite; Hbl = hornblende; Cpx = clinopyroxene; $\mathrm{Pl}=$ plagioclase and $\mathrm{Fsp}=$ feldspar.

altered and were omitted from our compilation and for any further discussion.

\section{Whole-rock geochemistry}

\subsection{Analytical procedures}

\subsubsection{Major, trace and rare elements data}

A total of 94 samples were analyzed by X-ray fluorescence spectrometry (XRF) (Panalytical Model
Philips Magix Pro Model 2440) at University of Delhi, Delhi, for their major and a few trace elements composition, following Longjam and Ahmad (2012). Out of 94 samples, 42 samples were selected for the analyses of trace elements including rare earth elements (REE) using ICP-MS (Perkin Elmer, Sciex Elan DRC II) at Indian Institute of Technology (IIT), Roorkee as a part of our study for whole-rock trace elements, and rare earth elements (REEs) (table 1a-d). The precision of the ICP-MS data was $\pm 4.1 \%$ RSD. The procedure for ICP-MS 


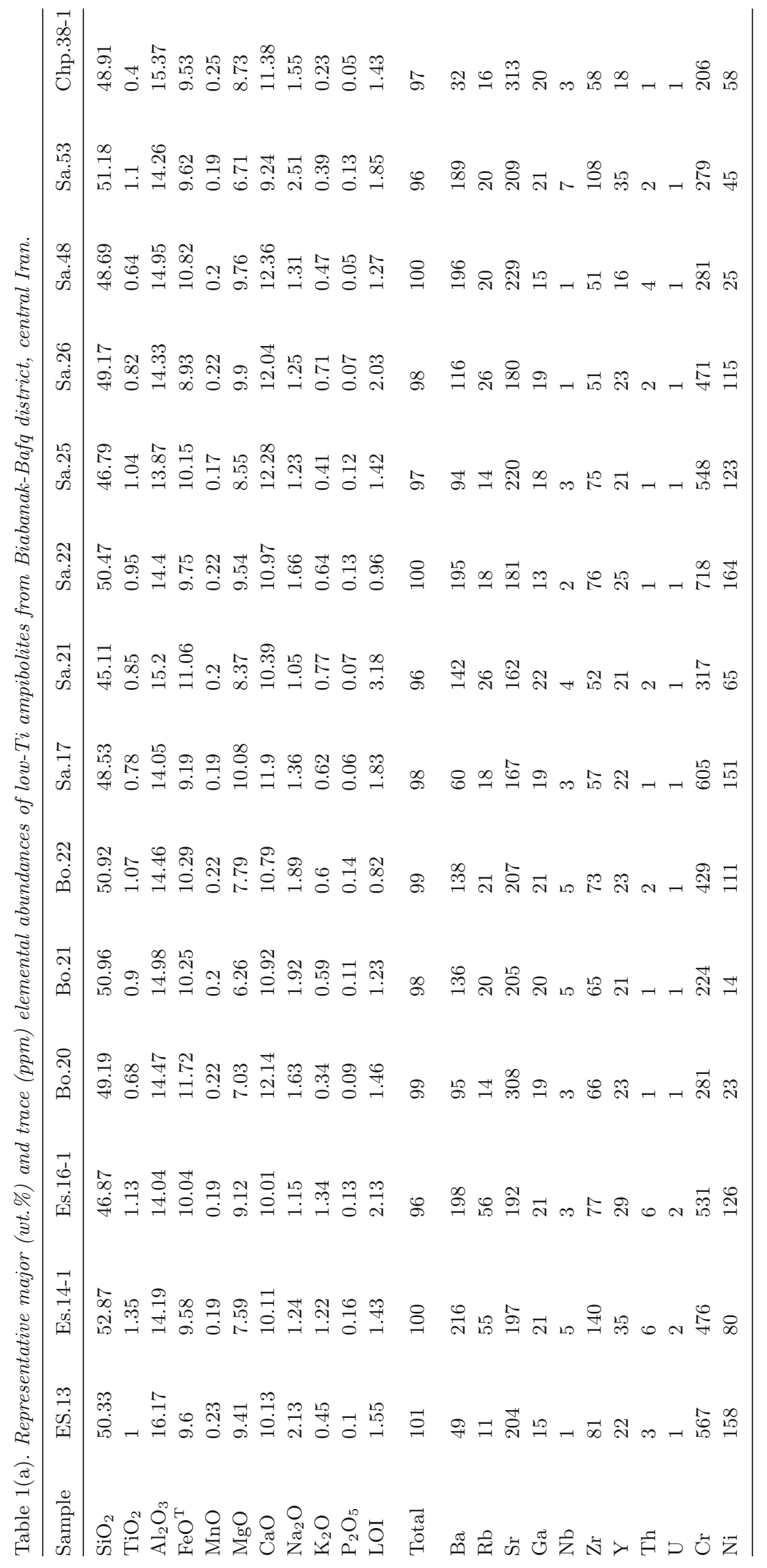




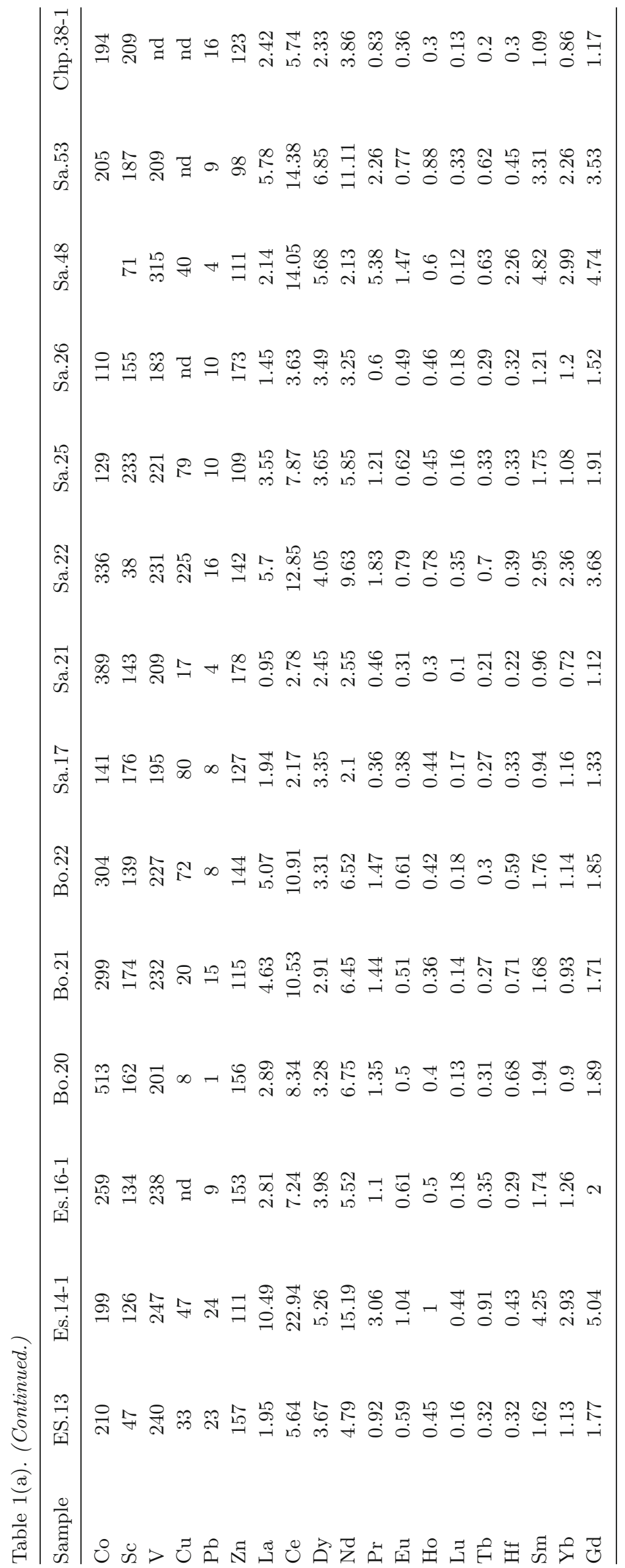




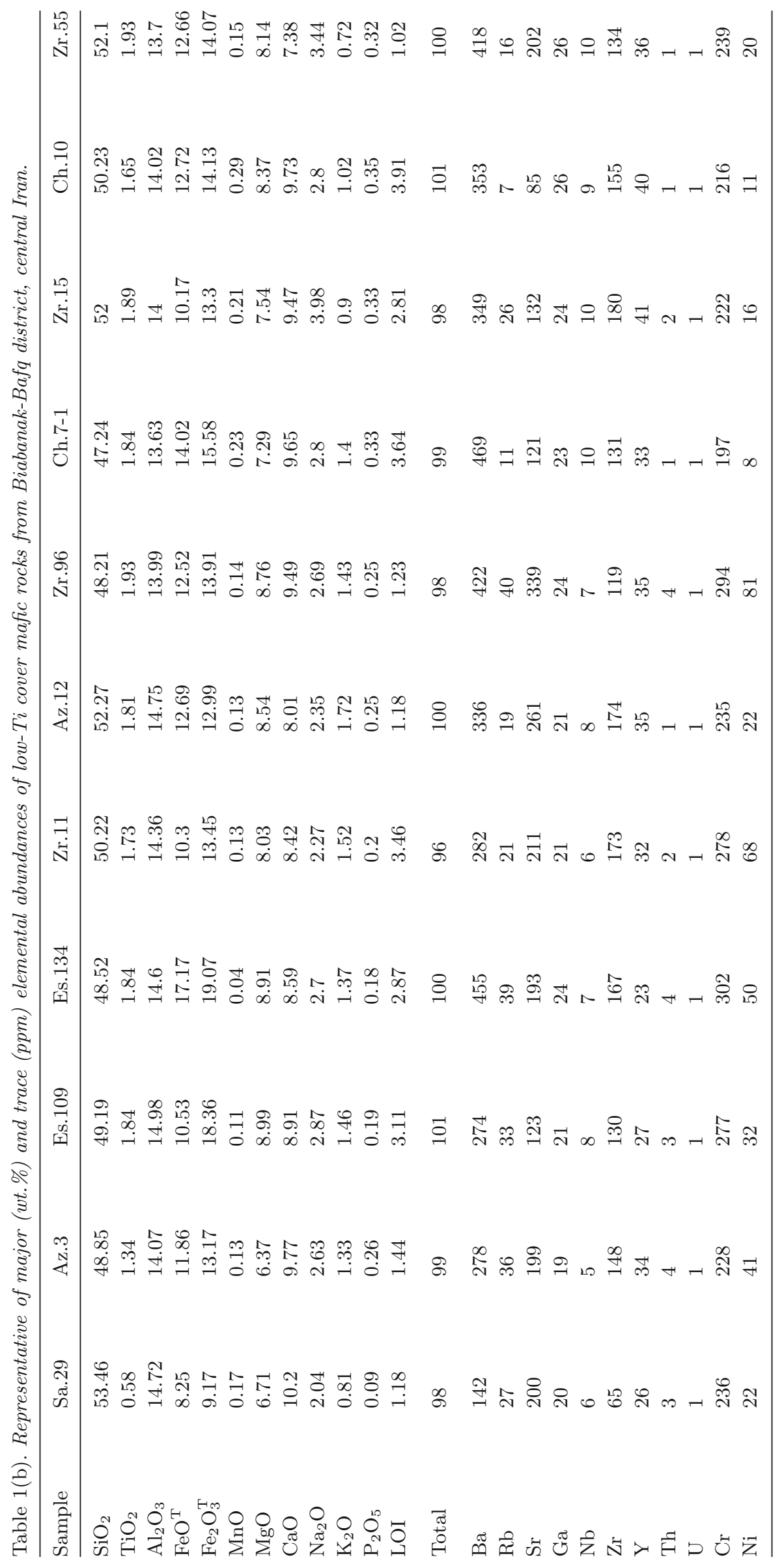




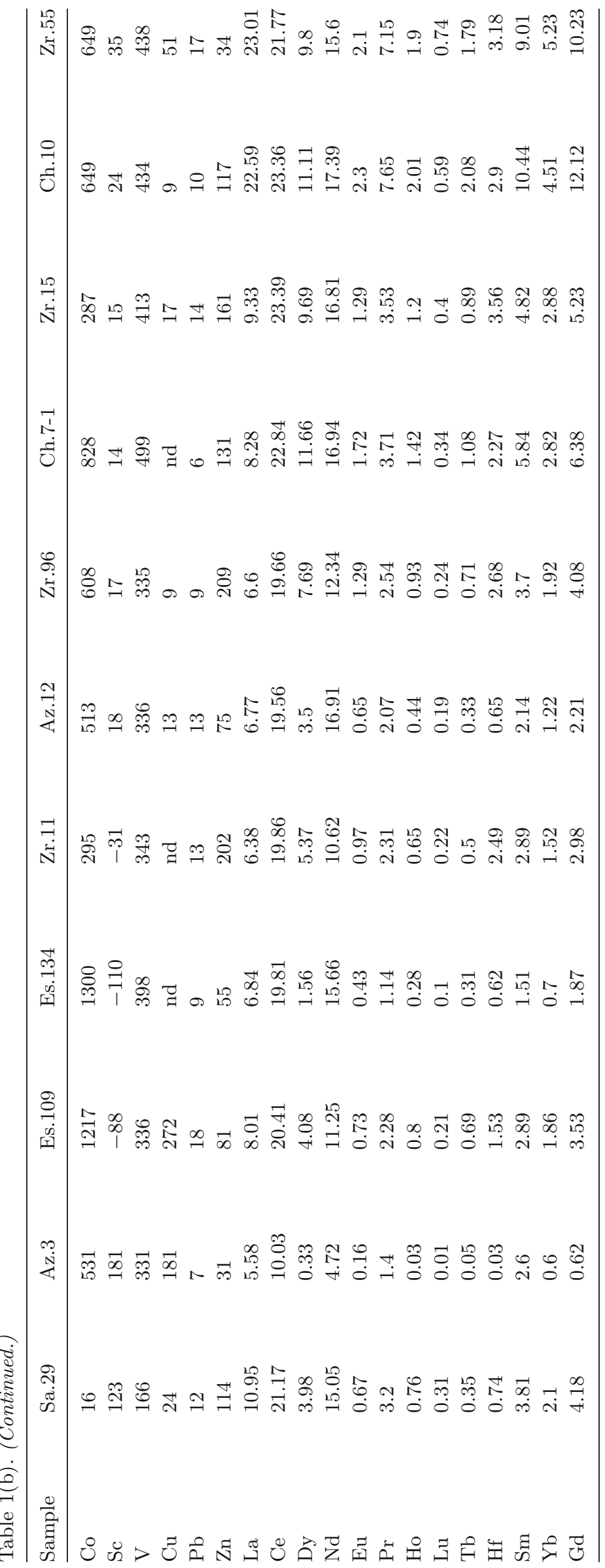




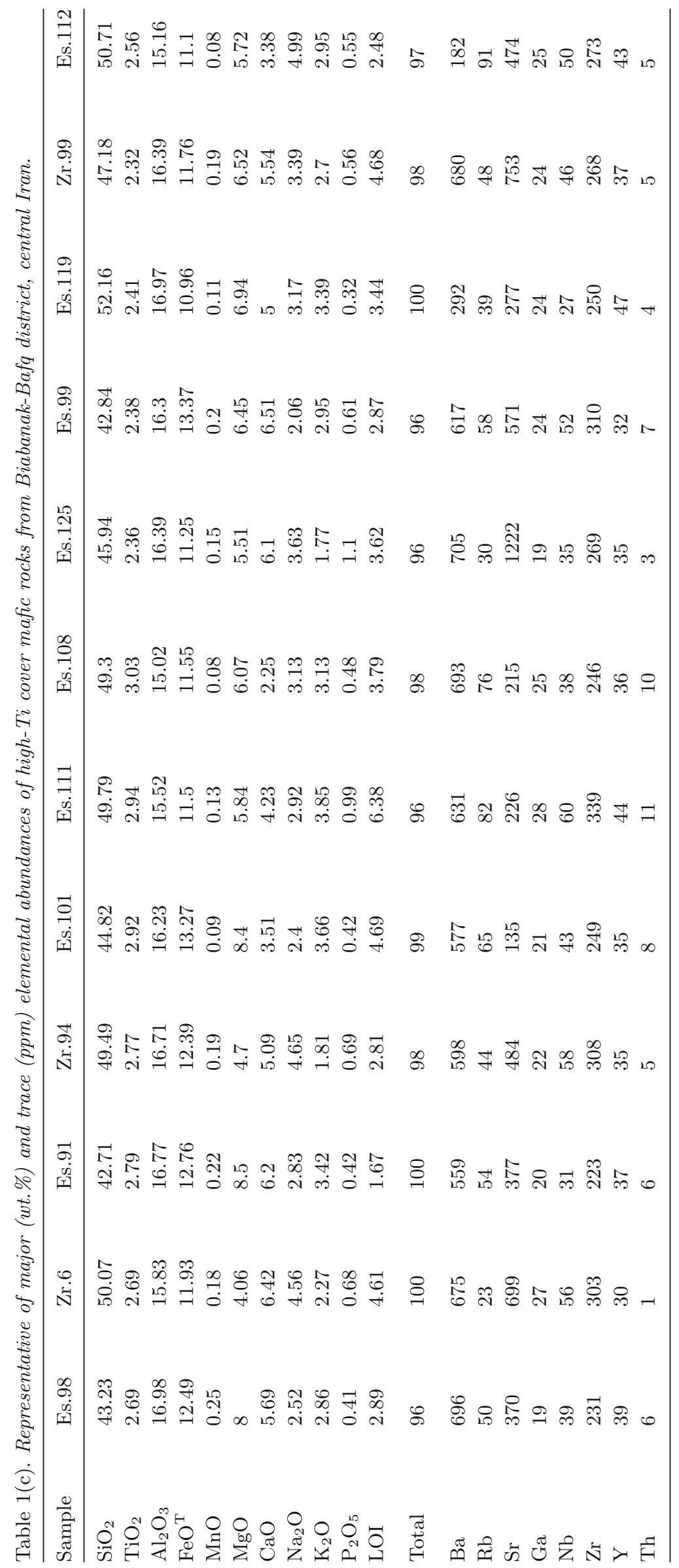




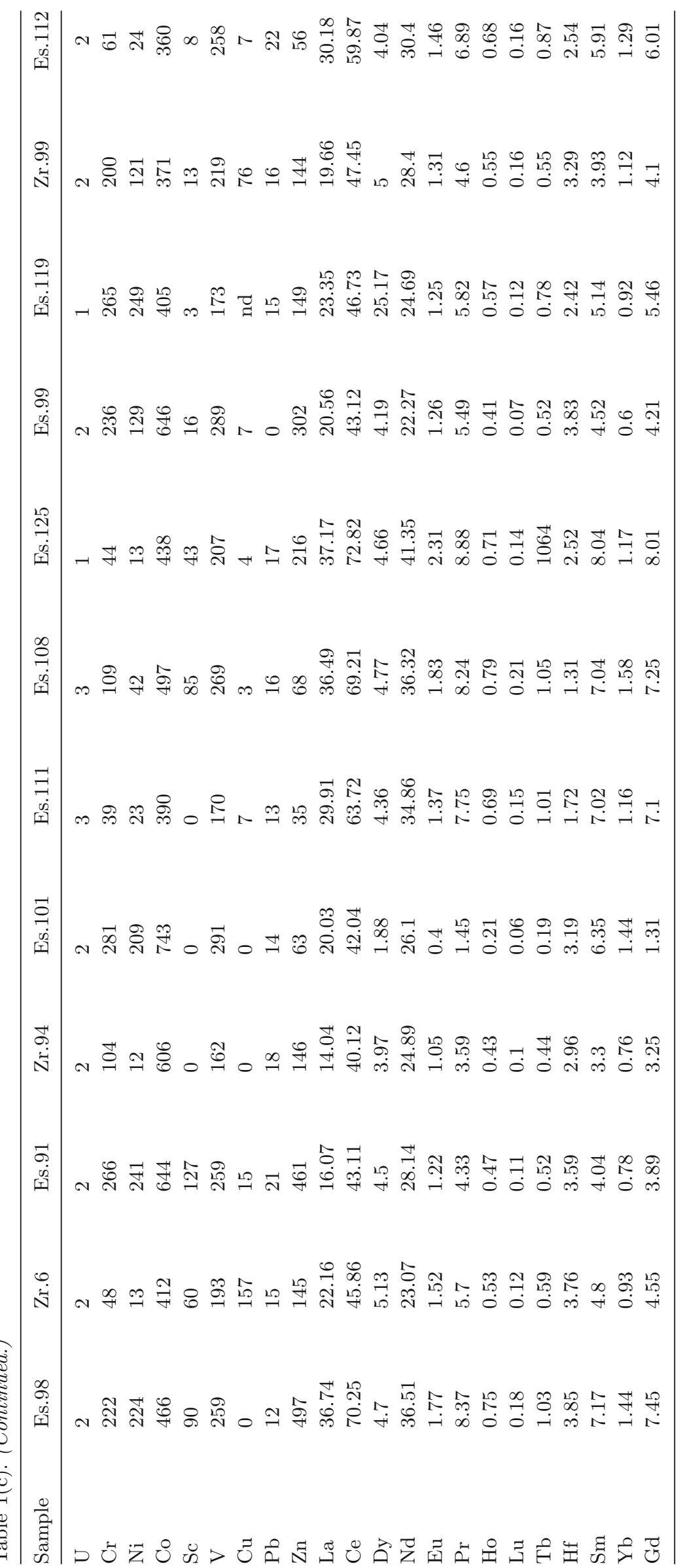




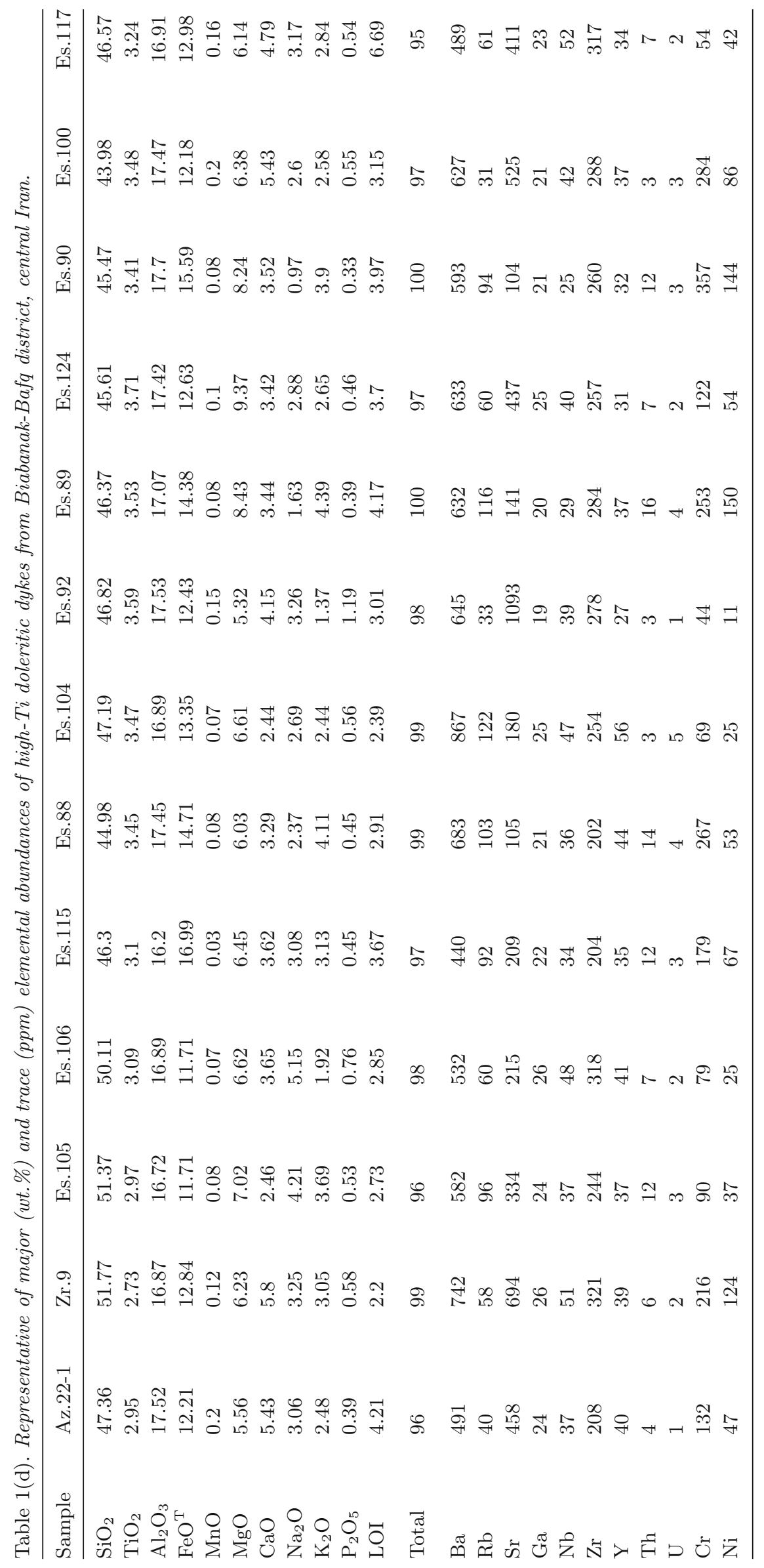




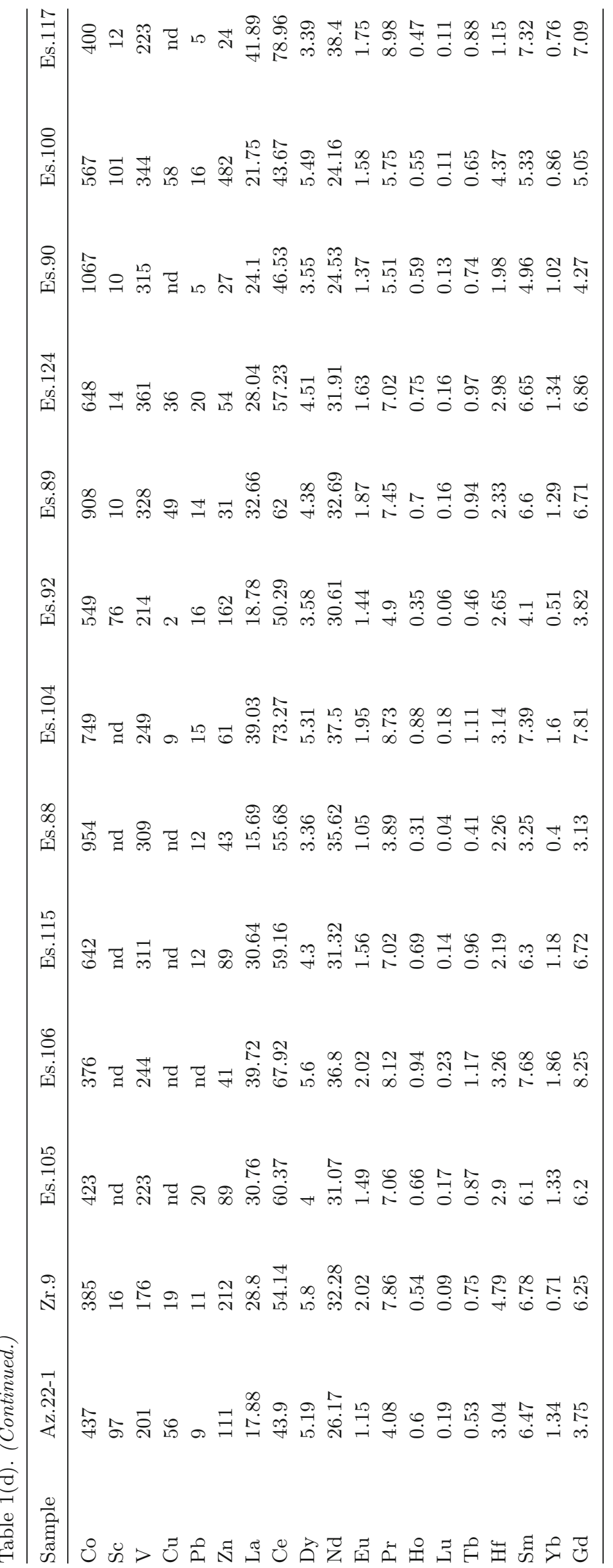


analysis is described in Bhattacharya et al. (2010, 2011).

\subsubsection{Whole rock $\mathrm{Sr}$ and $\mathrm{Nd}$ isotopic data}

${ }^{143} \mathrm{Nd} /{ }^{144} \mathrm{Nd}$ and ${ }^{87} \mathrm{Sr} /{ }^{86} \mathrm{Sr}$ ratios for samples were determined on the multi-collector Finnigan-MAT 262 mass spectrometer at Institute of Instrument Centre (IIC), Indian Institute of Technology (IIT), Roorkee by using a double-collector dynamic algorithm and normalized to ${ }^{146} \mathrm{Nd} /{ }^{144} \mathrm{Nd}=0.7219$ with a linear fractionation correction. ${ }^{147} \mathrm{Sm} /{ }^{143} \mathrm{Nd}$ ratios were determined by isotope dilution on separate aliquots (Bickle 1986). The $\mathrm{Nd}$ and $\mathrm{Sr}$ isotopic measurements were carried out following the procedure involving digestion of $0.1-0.3 \mathrm{~g}$ sample powders by standard acid mixture technique. The standard replicates showed a precision of $0.0035 \%(2 \sigma)$ for $\mathrm{Nd}$ and $0.0045 \%(2 \sigma)$ for Sr. ${ }^{87} \mathrm{Sr} /{ }^{86} \mathrm{Sr}$ ratios were analyzed using a triple collector dynamic algorithm and normalized to ${ }^{86} \mathrm{Sr} /{ }^{88} \mathrm{Sr}=0.1194$ with an exponential fractionation correction.

\subsection{Geochemical characterization}

Zirconium is one of the most immobile elements during low-grade alteration of basaltic rocks and is essentially incompatible in basaltic rocks (Tarney et al. 1979). To illustrate this, we have plotted major and trace elements against $\mathrm{Zr}$ as an index of fractionation in Harker diagrams (figure 4b-1). $\mathrm{MgO}$ and $\mathrm{FeO}^{\mathrm{t}}$ against $\mathrm{Zr}$ are given in figure 4(c and e) that show a sharply decreasing trend for $\mathrm{MgO}\left(16-2\right.$ wt.\%) and $\mathrm{FeO}^{\mathrm{t}}(20-2$ wt.\%). The low-Ti basement mafic rocks were observed to be rich in $\mathrm{Mg}$ and low- to high-Ti cover mafic rocks rich in Fe. In binary diagrams, $\mathrm{TiO}_{2}$ vs. $\mathrm{Zr}$ (figure $4 \mathrm{~g}$ ), $\mathrm{P}_{2} \mathrm{O}_{5}$ vs. $\mathrm{Zr}$ (figure $4 \mathrm{f}$ ), and $\mathrm{Y}$ vs. $\mathrm{Zr}$ (figure $4 \mathrm{i}$ ) indicate both major and trace elements increased linearly with increasing $\mathrm{Zr}$, which is supposed in the basaltic rocks. For the suite of samples used, the other major elements ( $\mathrm{Al}, \mathrm{Ti}$ ) appear to define cohesive magmatic trends and the high field strength trace elements ( $\mathrm{Nb}, \mathrm{Hf}, \mathrm{Zr}, \mathrm{Y}$ ), and the rare earth elements (REE) display smooth trends in chondrite-normalized diagrams indicating that they have been relatively immobile. To assess the mobility of individual elements during post crystallization processes, we have plotted a few known mobile elements such as $\mathrm{Ba}, \mathrm{Sr}$, and $\mathrm{Na}_{2} \mathrm{O}, \mathrm{K}_{2} \mathrm{O}$ against $\mathrm{Zr}$, these elements also show consistent trends, indicating that most of the major and trace elements were not perturbed (figure 4i-l). Major element ratio plots, $\mathrm{MgO} / \mathrm{TiO}_{2}$ vs. $\mathrm{CaO} / \mathrm{TiO}_{2}$, $\mathrm{Al}_{2} \mathrm{O}_{3} / \mathrm{TiO}_{2}$ and $\mathrm{CaO} / \mathrm{TiO}_{2}$ vs. $\mathrm{TiO}_{2}$ show tight magmatic trends (Nesbitt et al. 1979). Normalized REE and complimentary multi-element patterns are regular and consistent with magmatic processes, implying that the incompatible trace element abundance and their ratios appear to reflect near primary magma characteristics (figure $5 \mathrm{a}-\mathrm{f}$ ).

\subsubsection{Classification and magma series}

The mafic rocks of Biabanak-Bafq district have been classified on the basis of geochemical studies in three groups as (a) low-Ti basement amphibolites; (b) low-Ti cover mafic rocks and (c) high-Ti cover alkali mafic rocks and doleritic dykes. Besides, alkaline basalts generally have higher average $\mathrm{TiO}_{2}$ than tholeiitic basalts and thus caution must be paid to distinguish 'higher than average-Ti' tholeiitic basalts from alkaline basalts because their origin is distinct (e.g., Cummins et al. 1992). High-Ti alkali mafic cover rocks, as well as doleritic dykes, depict similar geochemical characteristics and enriched sources. We suggest that the doleritic dykes could have acted as feeder dykes for the Ti-rich cover mafic volcanic and gabbroic bodies. Petrographic studies of the investigated mafic magmatic rocks indicate that some of the samples are slightly altered; samples with more than 2\% LOI are discarded. Geochemical classification based on immobile trace elements is very useful in this case. One of the most useful discrimination diagrams for the altered or metamorphosed rocks is $\log -\log \mathrm{Zr} / \mathrm{Ti}$ against $\mathrm{Nb} / \mathrm{Y}$ diagram (figure 4a; Pearce 1996), which has been used for the classification of the Biabank-Bafq district samples. The majority of the low-Ti samples plot within the basalt and andesitic basalt fields, a majority of the high-Ti samples plot in the alkali basalt field, with a few samples plot in a basanite/nephelinite field. The low- to high$\mathrm{Ti}$ cover mafic rocks occur as volcanic rocks and hypabyssal intrusive bodies and associated mafic dykes. Plotting on the $\mathrm{Nb} / \mathrm{Y}-\mathrm{Zr} / \mathrm{P}_{2} \mathrm{O}_{5}$ discrimination binary diagram (Winchester and Floyd 1977), low-Ti basement amphibolites along with low-Ti of the cover mafic rocks and high-Ti of the cover mafic rocks of Biabank-Bafq district distinctly indicate tholeiitic and alkaline nature, respectively. All these low- to high-Ti cover mafic rocks indicate $\mathrm{Fe}$ enriched nature. Observation of negative trends in major elements (e.g., $\mathrm{MgO}, \mathrm{CaO}, \mathrm{Al}_{2} \mathrm{O}_{3}$, 

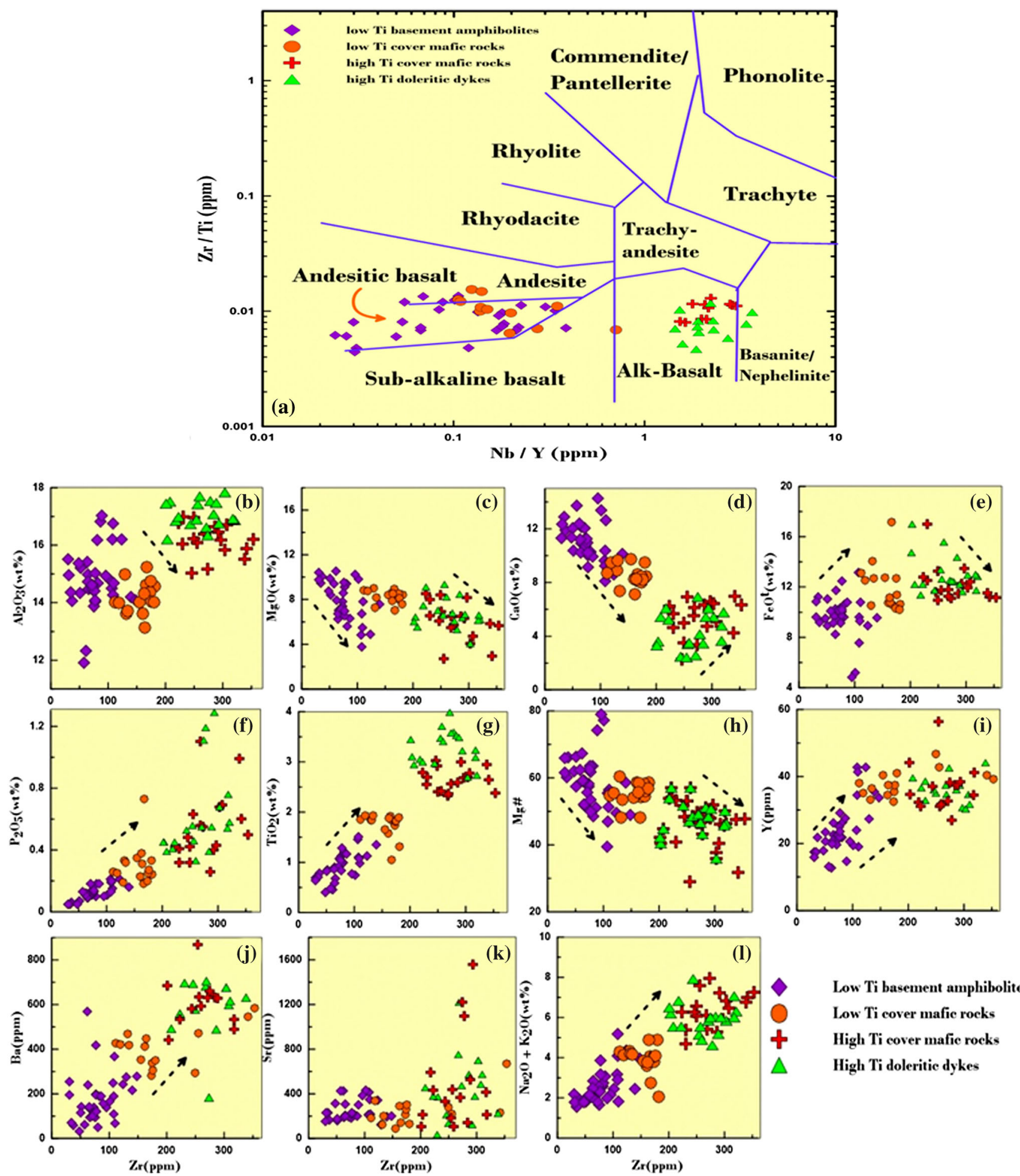

Low Ti basement amphibolites Low $\mathrm{Ti}$ cover mafic rocks High Ti cover mafic rocks High Ti doleritic dykes

Figure 4. (a) $\log \mathrm{Nb} / \mathrm{Y}$ vs. $\log \mathrm{Zr} / \mathrm{TiO}_{2}$. These diagrams are proposed by Winchester and Floyd (1977) for classification of volcanic rocks using incompatible element ratios. (b-l) Harker major and trace variation diagram from Biabanak-Bafq district.

$\mathrm{FeO}^{\mathrm{t}}$ vs. $\mathrm{Zr}$ ) and positive trends of $\mathrm{TiO}_{2}, \mathrm{P}_{2} \mathrm{O}_{5}$ and $\mathrm{Mg} \#$ ( $\mathrm{Mg}$ number) vs. $\mathrm{Zr}$ plots (figure $4 \mathrm{~b}-$ $\mathrm{h}$ ), indicate fractionation of olivine, pyroxene, plagioclase, and titano-magnetite crystals. The classic AFM diagram (Irvine and Barager 1971) confirmed a tholeiitic nature, as the investigated low-Ti basement and low- to high-Ti cover mafic rocks and the doleritic dykes are predominantly iron-rich (figure 6a). A diagram which is similar to AFM triangular plot, but is based on the 

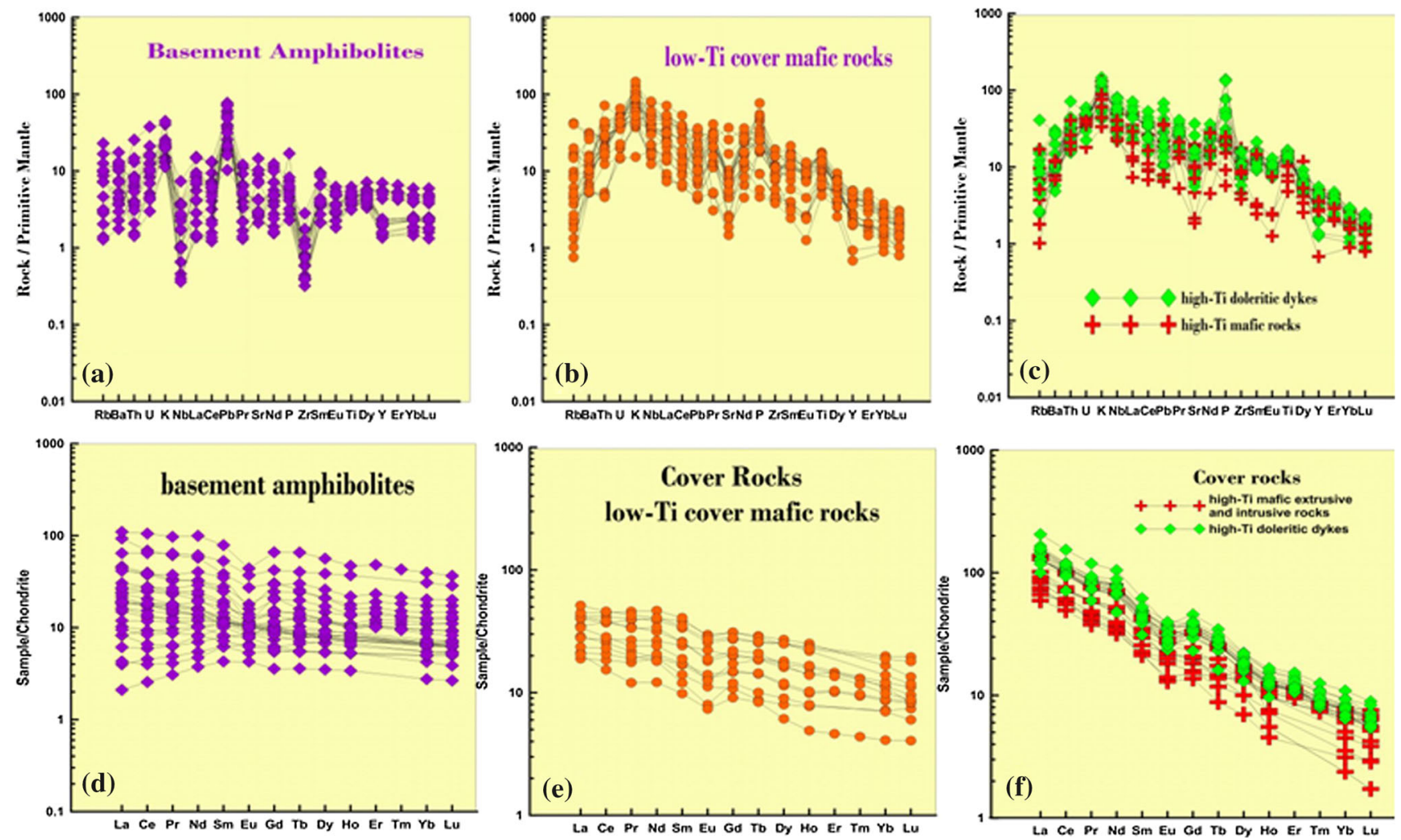

Figure 5. Chondrite, primitive mantle-normalized REE and trace patterns. Normalizing values from Sun and McDonough (1989).

elements $\mathrm{Ti}-\mathrm{Zr}+\mathrm{Y}-\mathrm{Cr}$ (Davies et al. 1979) that are normally immobile during alteration, shows that the samples follow a clear tholeiitic trend, with two distinct lineages being evident in the dykes (figure 6b). A triangular plot of cations of Al-Fe+Ti-Mg (Jensen 1976) shows that majority of low-Ti samples fall in the komatiitic basalt, whereas high-Ti samples occupy in the high-Fe field tholeiitic basalt (figure 6c). The low-Ti basement amphibolites are more towards $\mathrm{Mg}$ and $\mathrm{Fe}$ tholeiite fields and low-Ti cover mafic samples are distinctly Fe-tholeiite, whereas the high-Ti cover mafic suite and dyke samples have Fe-enriched alkaline nature. Geochemical data thus reveal that the low-Ti basement amphibolites and cover mafic rocks is tholeiitic in nature, whereas the high-Ti cover mafic rocks as well doleritic dykes are alkaline in nature and showing considerably more $\mathrm{Fe}$ enrichment than the low-Ti mafic samples.

\subsubsection{Nd-Sr isotope geochemistry}

The investigated mafic rocks have calculated $\mathrm{Nd}$ model age ( $\mathrm{T}_{\mathrm{DM}}$; table $2 \mathrm{a}$ and $\left.\mathrm{b}\right)$, indicating average crustal residence time of $1.5 \mathrm{Ga}$. The
Nd model ages $\left(\mathrm{T}_{\mathrm{DM}}\right)$ for basement amphibolites varies in the range of $1.22-2.93 \mathrm{Ga}$ (figure $7 \mathrm{a}$ ), with the corresponding $\varepsilon \mathrm{Nd}$ at $1.5 \mathrm{Ga}$ varying from -17.20 to +3.92 and demonstrating that the Saghand region might have experienced interaction of depleted mantle derived magmas with older crust (Nelson and Davidson 1993) (figure $7 \mathrm{~b}$ ). The negative epsilon values indicate long crustal residence for the basement samples. $\mathrm{Nd}$ model ages $\left(\mathrm{T}_{\mathrm{DM}}\right)$ for low-Ti, high-Ti and dolerites from cover rocks varied in the range of 0.86 $1.42,1.19-1.91$ and $1.01-1.69 \mathrm{Ga}$, respectively. The corresponding $\varepsilon \mathrm{Nd}$ at $1.5 \mathrm{Ga}$ varies from -4.71 to $+3.67,+0.85$ to $+3.33,-3.53$ to 2.19 and -1.02 to +6.66 , respectively indicating that the Biabank-Bafq district might have experienced the interaction of depleted mantle derived magmas with older crust (Nelson and Davidson 1993) (figure $7 b$ ).

The initial ${ }^{87} \mathrm{Sr} /{ }^{86} \mathrm{Sr} \quad(1.5 \mathrm{Ga})$ vs. initial ${ }^{143} \mathrm{Nd} /{ }^{144} \mathrm{Nd}(1.5 \mathrm{Ga})$ indicates the derivation of low-Ti basement amphibolites, low- to high-Ti cover mafic rocks as well as doleritic dykes from enriched mantle similar to (EMI and EMII) sources (figure 8). In ${ }^{143} \mathrm{Nd} /{ }^{144} \mathrm{Nd}$ ratios vs. ${ }^{87} \mathrm{Sr} /{ }^{86} \mathrm{Sr}$ 


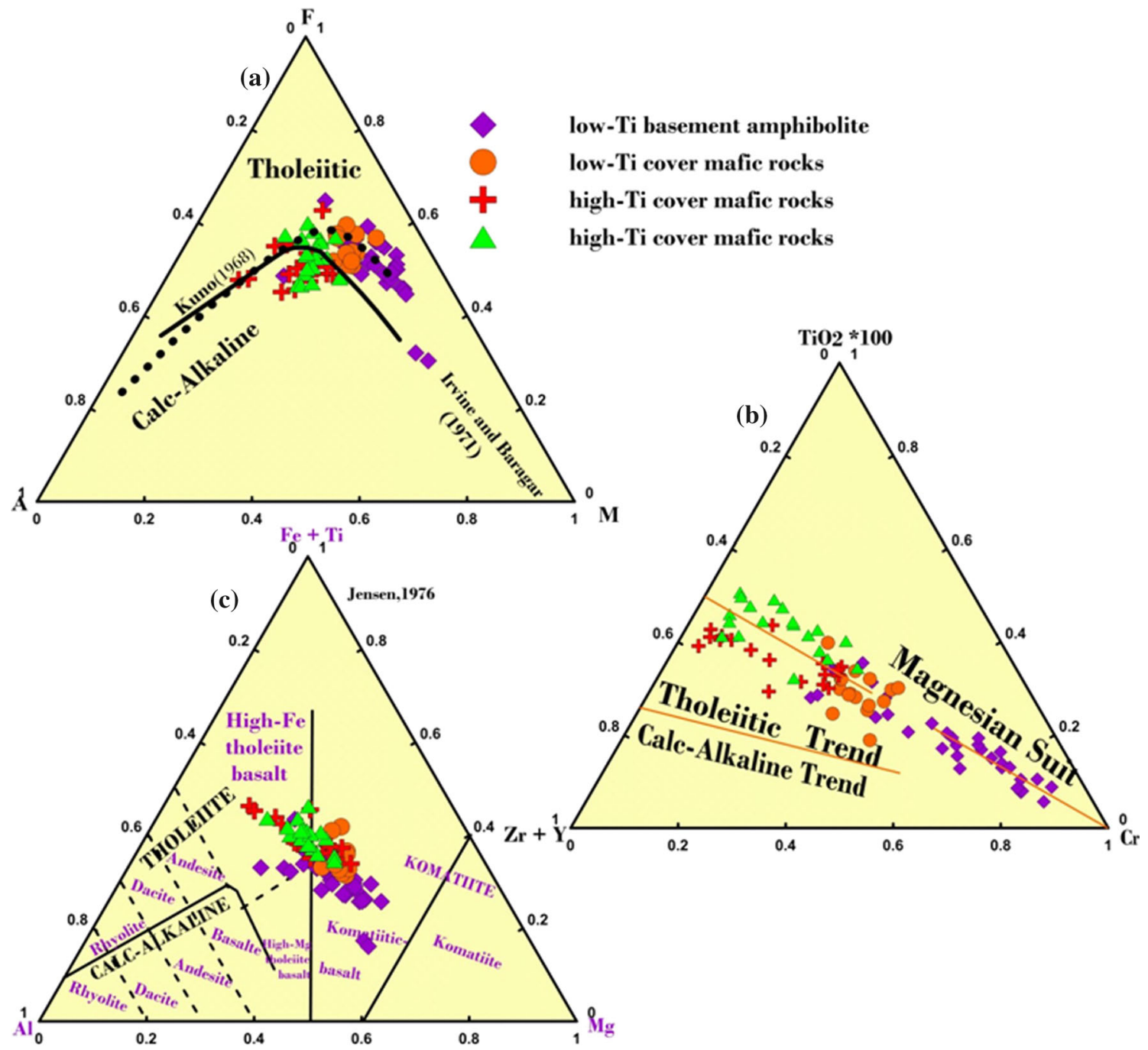

Figure 6. Triangular plots of (a) AFM (Irvine and Barager 1971); (b) (Zr+Y)-TiO2*100-Cr (Davies et al. 1979); and (c) cation percent $\mathrm{A} 1-(\mathrm{Fe}+\mathrm{Ti})-\mathrm{Mg}$ (Jensen 1976), all illustrating the tholeiite nature of the Posh-e-Badam block rocks.

evolution diagram (figure 8), the low-Ti amphibolites and low- to high-Ti cover mafic samples of Biabanak-Bafq district plot in the enriched mantle source between EMI $(<0.5112)$ and EMII (0.5121) type source (Rollinson 1993). However, both of them follow the mixed mantle-crust source, but more likely towards enriched mantle source.

\section{Discussion}

\subsection{Petrogenesis of mafic rocks}

Low-Ti cover mafic rocks are distinctly enriched in incompatible elements such as large ion lithophile elements (LILE) and light REE (LREE) compared to primordial mantle abundances, but have an equally distinct "continental" signature reflected in marked less $\mathrm{Nb}, \mathrm{Sr}, \mathrm{P}$ and $\mathrm{Ti}$ anomalies (Ahmad and Tarney 1991; Tarney 1992) in their mantle-normalized spidergrams (figure $5 \mathrm{a}-\mathrm{c}$ ). These geochemical features may have close similarities with Proterozoic continental flood basalt (CFB) signatures (Tarney 1992). These signatures were probably imposed upon the sub-continental lithosphere at the time of continental crustal evolution. The high-Ti mafic rocks and doleritic dykes show LREE and LILE enrichment and high field strength elements (HFSE) depletion (figure 5df). The whole-rock chemical composition of the low-Ti cover rocks (mafic dykes and gabbro) is consistent with fractional crystallization of an assemblage of olivine \pm clinopyroxene \pm plagioclase, probably derived from CFB-like magmas, 


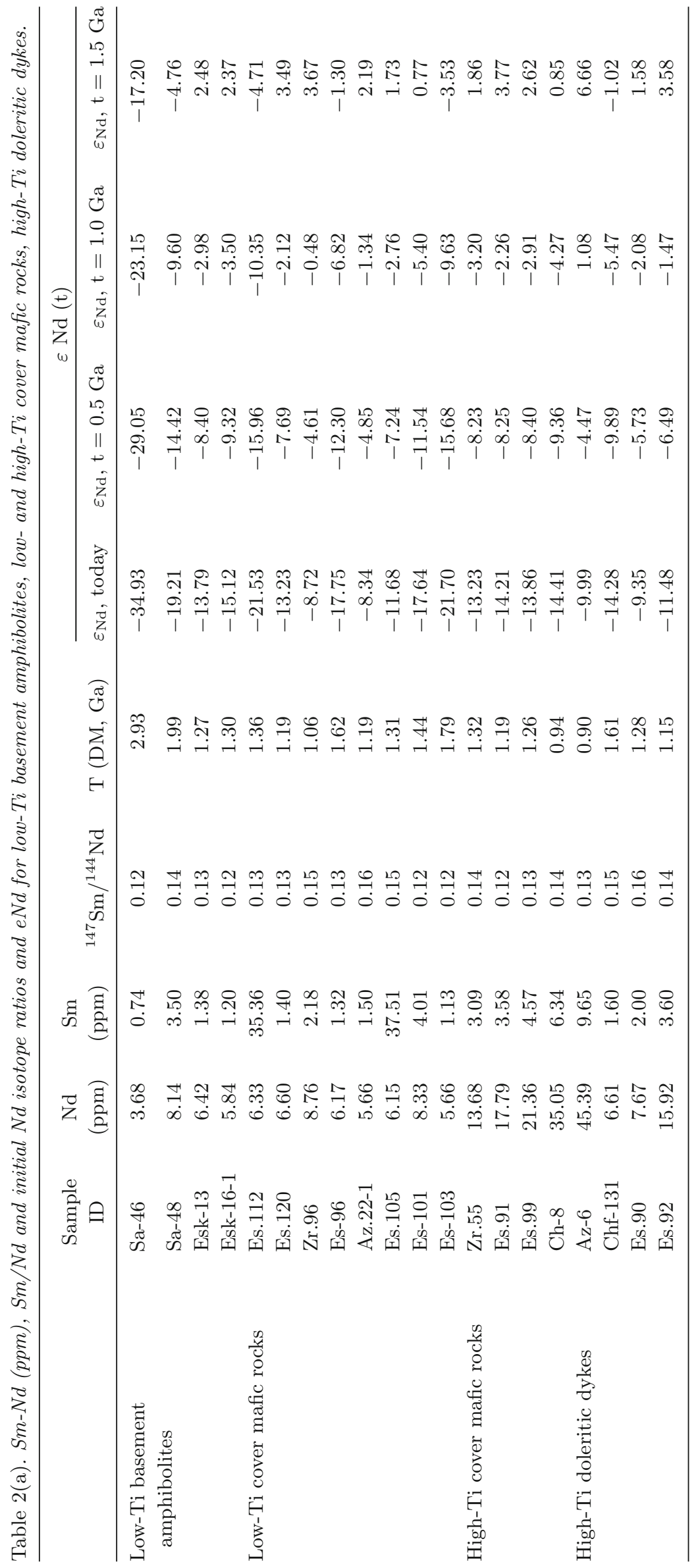




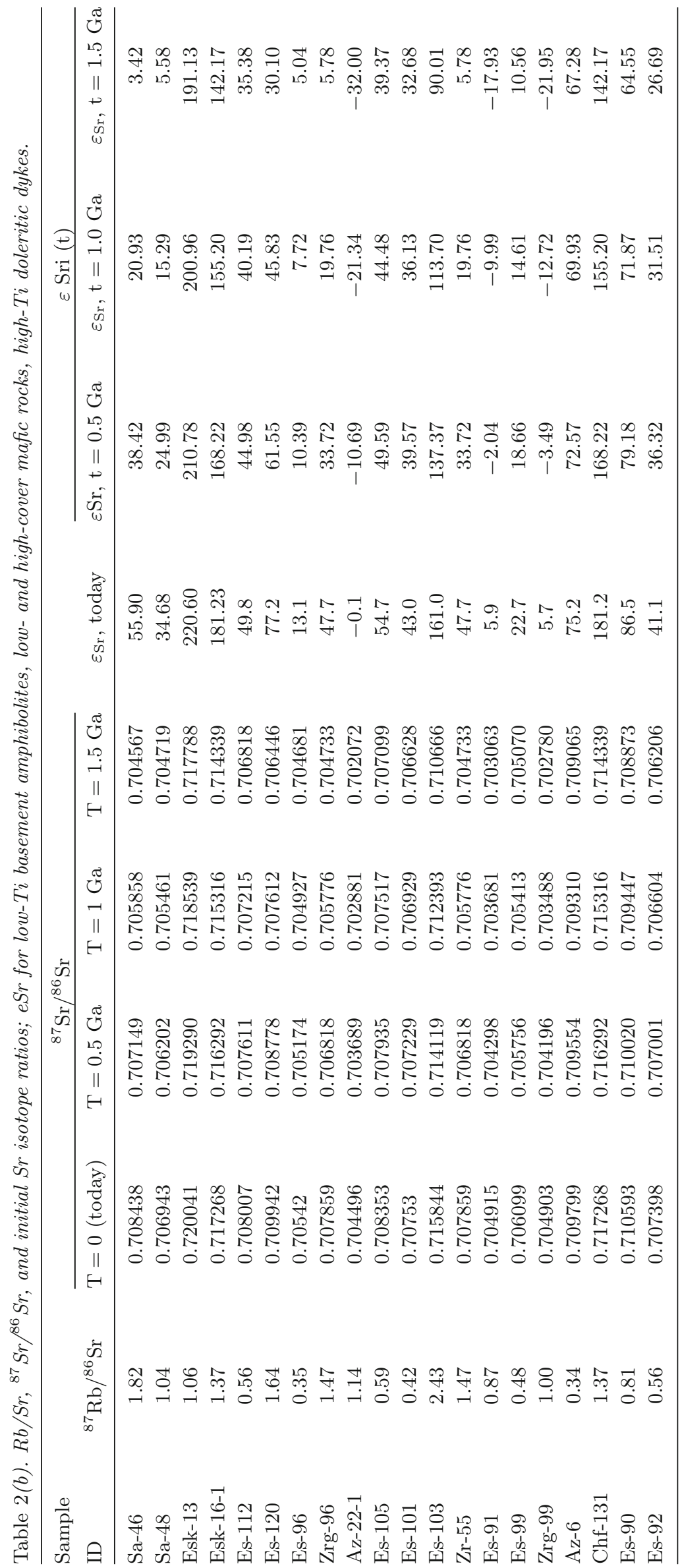


(a)

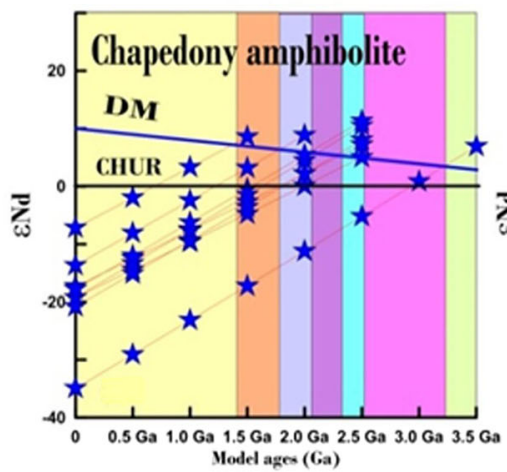

(b)

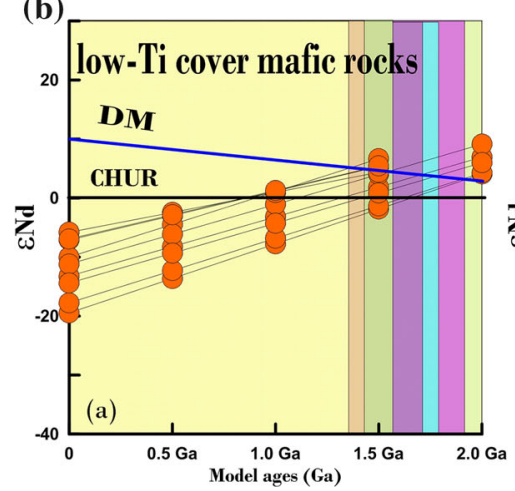

$\star \star \star \star$ basement amphibolite
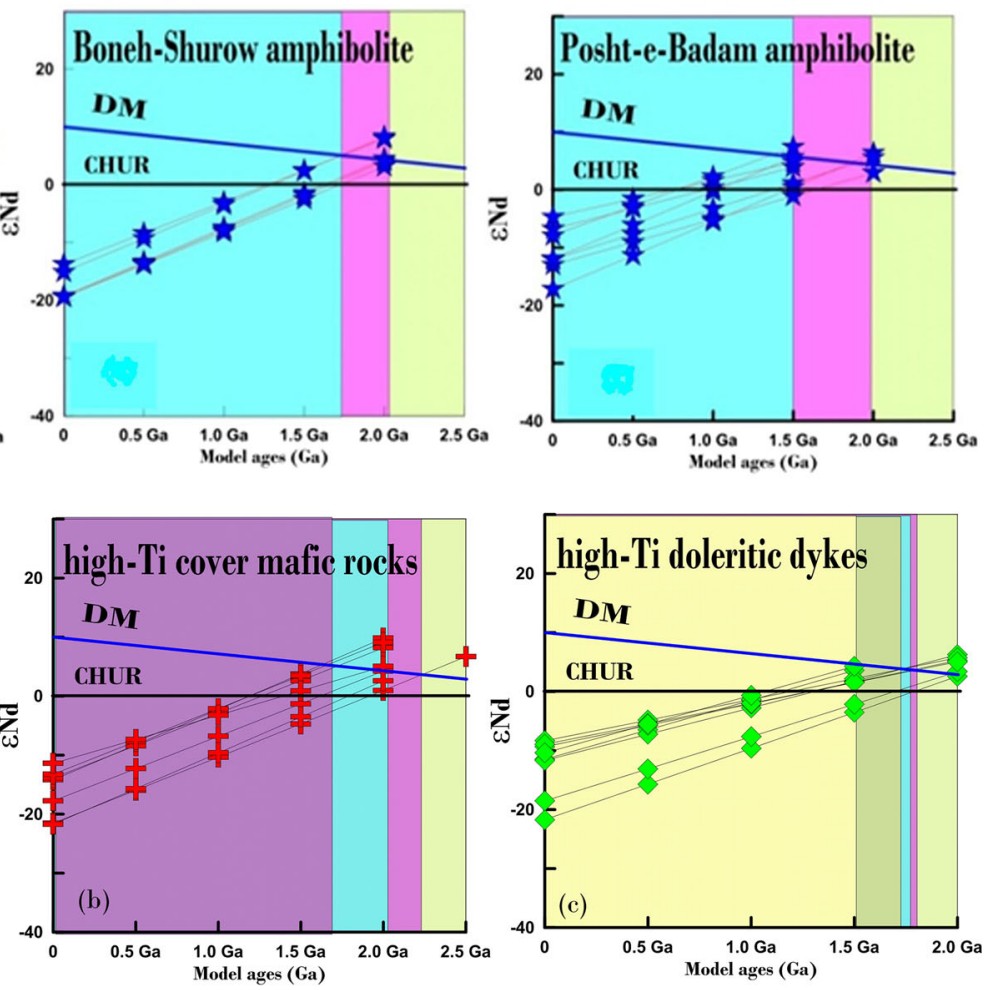

Figure 7. (a) Evolution of $\varepsilon \mathrm{Nd}$ growth curves for basement amphibolites. (b) Evolution of $\varepsilon \mathrm{Nd}$ growth curves for cover mafic rocks. DM and CHUR lines are taken from Rollinson (1993) refereed.

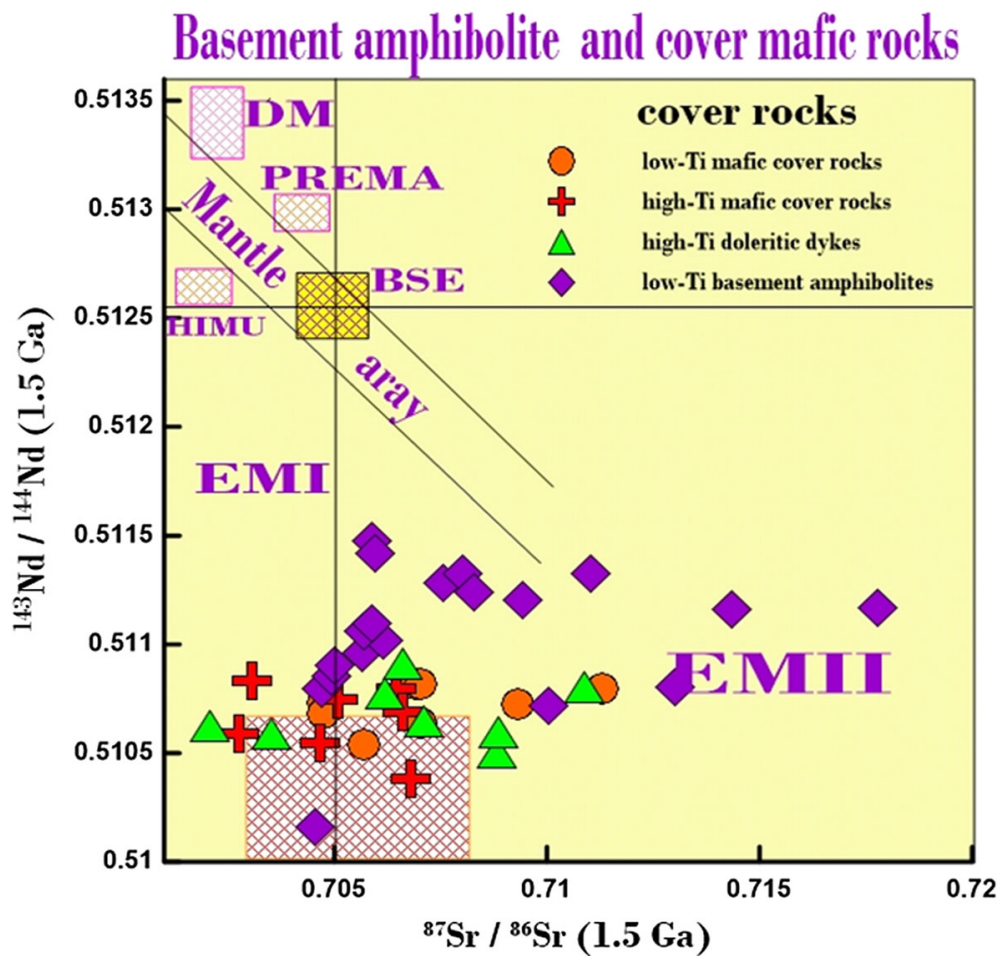

Figure 8. Comparison of basement amphibolites with cover mafic rocks in evolution of initial ${ }^{143} \mathrm{Nd} /{ }^{144} \mathrm{Nd}$ vs. ${ }^{87} \mathrm{Sr} /{ }^{86} \mathrm{Sr}$ diagram. DM and CHUR lines are taken from Rollinson (1993). 
it also suggests some contributions from crustal contamination. Low-Ti cover mafic samples contain a crustal component in the form of an increase in $\mathrm{La} / \mathrm{Yb}$ with $\mathrm{Zr} / \mathrm{Nb}$ ratios. In contrast, voluminous high-Ti mafic magmatic samples and doleritic dykes of this terrane display an increase in $\mathrm{La} / \mathrm{Yb}$ with a decrease in $\mathrm{Zr} / \mathrm{Nb}$ ratios, indicative of an alkaline mantle component. REE patterns indicate that low- to high-Ti cover rock samples can potentially be related to each other through varying degrees of partial melting of similar sources followed by gabbroic fractionation with plagioclase as an important phase. Low-Ti basement amphibolites depict large variation from low- to high-LREE patterns (figure $5 \mathrm{~d}$ ), which resemble island arc tholeiites (IAT), mid-ocean ridge basalts (MORB) and the high-Ti samples resemble ocean-island basalts (OIB) (after Sun and McDonough 1989; Greenough et al. 1990, 2007). Island arc tholeiites have flat to slightly enriched REE profiles, much less pronounced than OIB, whereas MORB show LREE depletion. These gently sloping profiles are consistent with the generation of magma in the shallow (spinel lherzolite) mantle. High-Ti cover mafic samples with highly enriched REE patterns $\sim 50$ to 120 times chondrite illustrate the derivation of these rocks from rather deeper (garnet lherzolite) and enriched mantle source(s) (figure 5f). OIB shows severely depleted HREE pattern indicating a presence of garnet in the source. The different REE patterns, which are observed in all the investigated rocks indicate the heterogeneous source(s). Therefore, it can be assumed that heterogeneous source and melting conditions also played a significant role in the generation of these rocks.

In the case of high-Ti mafic samples, low $\mathrm{K}_{2} \mathrm{O}$ / $\mathrm{P}_{2} \mathrm{O}_{5}$ (0.02-11.82), high $\mathrm{TiO}_{2} / \mathrm{P}_{2} \mathrm{O}_{5}(2.25-10.33)$, $\mathrm{La} / \mathrm{Nb}(0.75-9.59), \mathrm{Nb} / \mathrm{Th}>1.71$ and negative $\mathrm{Rb}$ anomaly probably reflects little contamination from the granitic continental crust. Geochemical compositions such as $\mathrm{Al}_{2} \mathrm{O}_{3} / \mathrm{TiO}_{2}$ (3.87-10.83), mid-to-high $\mathrm{TiO}_{2}$ (1.74-2.81 wt.\%), positive $\mathrm{Nb}$ anomalies and LREE enrichment of the BiabanakBafq district samples attest to their OIB type signature, which probably got derived from enriched mantle source similar to EMI. Ba/Th (11.01-187), $\mathrm{Ba} / \mathrm{La}(2.33-12.33)$ and $\mathrm{Th} / \mathrm{Nb}(0.07-0.10)$ ratios suggest that the source enrichment process was marked by recycling of sediments into the mantle through subduction (Hergt et al. 1989). The ratios of $\mathrm{Zr} / \mathrm{Hf}(28.57-56.11)$ and $\mathrm{Zr} / \mathrm{Ba}(0.08-3.13)$ indicate the involvement of a deeper mantle source.
The $\mathrm{Ce}$ and $\mathrm{Nd}$ relationship is used to evaluate the crustal contamination. Horan et al. (1987) observed that in a Ce vs. Nd plot, the mantle derived melt that gets affected by progressive crustal contamination or assimilation fractional crystallization (AFC) lie along the lines intersecting the $\mathrm{Nd}$ axis and do not pass through the origin. In the Ce vs. Nd diagram (figure 9a), the low-Ti cover mafic intrusive rocks follow the trend passing through the origin and occupy the place between calculated 2 and $10 \%$ partial melting of primitive mantle (Sun and McDonough 1989), which indicates that the source of these rocks was enriched in light rare earth elements (LREE). The incompatible trace element ratios such as $\mathrm{Zr} / \mathrm{TiO}_{2}, \mathrm{Zr} / \mathrm{Y}$, $\mathrm{La} / \mathrm{Nb}$ and $\mathrm{Ce} / \mathrm{Nb}$ are not affected by processes of fractional crystallization and higher degrees of partial melting (Condie 1990a, b), thus the values of such ratios observed in the low-Ti mafic rocks appear to be source derived. Fractionation of plagioclase and olivine cannot alter the $\mathrm{Zr} / \mathrm{Y}$ ratios, but fractionation of amphibole and clinopyroxene may raise the ratio with increasing $\mathrm{Zr}$ content (Ahmad and Tarney 1991; Floyd 1993; Ahmad et al. 1999; Kumar and Ahmad 2007). Thus, the positive correlation between $\mathrm{Zr} / \mathrm{Y}$ and $\mathrm{Zr}$ shown by the dolerites and high-Ti mafic rocks indicate fractionation of clinopyroxene. However, the positive correlation between $\mathrm{Zr} / \mathrm{Y}$ and $\mathrm{Zr}$ can also be produced by the decreasing degree of partial melting (figure 9b). Two calculated partial melting curves (Drury 1983) corresponding to two sets of source mineralogy (curve 1: olivine $60 \% \pm$ orthopyroxene $20 \% \pm$ clinopyroxene $10 \% \pm$ plagioclase $10 \%$; curve 2 : olivine $60 \% \pm$ orthopyroxene $20 \% \pm$ clinopyroxene $10 \% \pm$ garnet $10 \%$ ) for Archean mantle source (Sun and Nesbitt 1977) are shown in the diagram. Most of the studied samples plot along curve ' 2 ' indicating that the low-Ti group represent higher degrees of partial melting and the high-Ti group represent lower degrees of partial melting. Subsequent to their generation, most of these samples have experienced gabbroic fractionation involving olivine, clinopyroxene, and plagioclases as the dominant fractionating phase (figure $9 b$ ).

In the $\mathrm{Zr}$ vs. Ce and $\mathrm{Y}$ plots (figure 10a and b), the low-Ti basement amphibolites and a few of low-Ti cover mafic samples plot in the depleted field with respect to chondrite and primitive mantle lines, respectively. In the case of high-Ti cover mafic rocks and doleritic dykes, all the samples plot clearly in the enriched fields with respect to chondrite and primitive mantle lines. The high-Ti 

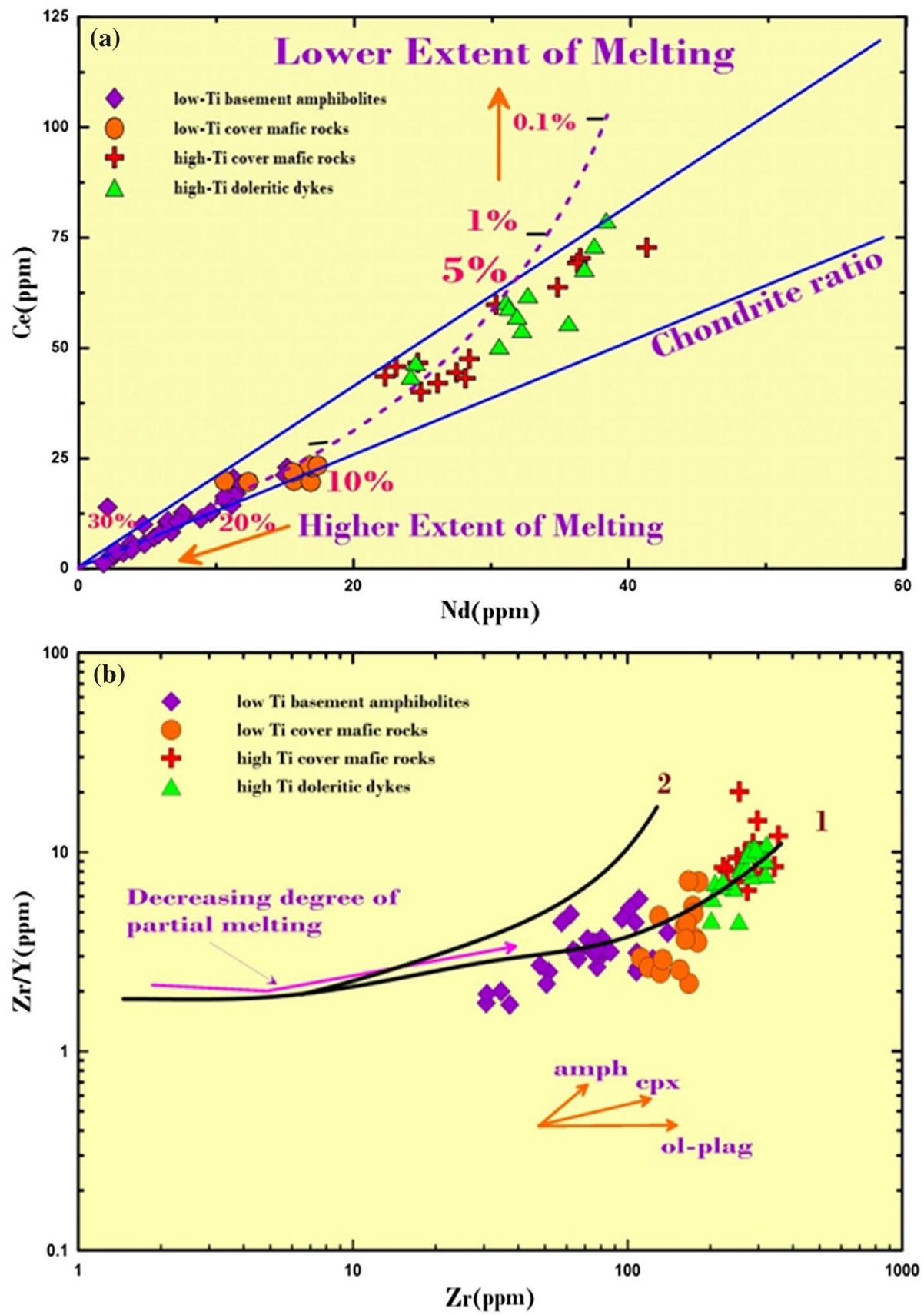

Figure 9. (a) Nd vs. Ce plot for mafic volcanics. Dashed line shows calculated different extents of melting for garnet lherzolite source. Melting calculations were performed using the Batch melting equations. Garnet lherzolite mineralogy and melting proportions from Hanson (1980) and REE abundances are from Sun and McDonough (1989); (b) Binary plot of Zr/Y vs. Zr; melting curves (1 and 2) are after Drury (1983) and vectors for fractional crystallization are after Floyd (1993).

cover alkaline mafic rocks along with dolerites are characterized by severe enrichment of LILE-LREEs and HFSE (Nb, P, and Ti) (figure 5c). However, the majority of the low-Ti basement and cover mafic samples have enriched LREE-LILE, but depleted in HFSE (figure $5 \mathrm{~d}$ and e). The enriched LREELILEs in low-Ti basement and cover mafic samples are an indication of their derivation from enriched sources, the depletion of HFSE in the case of low-Ti group probably indicate crustal/lithospheric influence (Tarney 1992). The negative Eu anomaly in low-Ti basement and cover mafic samples indicate fractionation of plagioclase during the evolution of these rocks. Depletion of $\mathrm{Nb}, \mathrm{P}$, Ti and Y relative to LILEs in low-Ti cover mafic samples indicate typical continental rift setting with some influence 

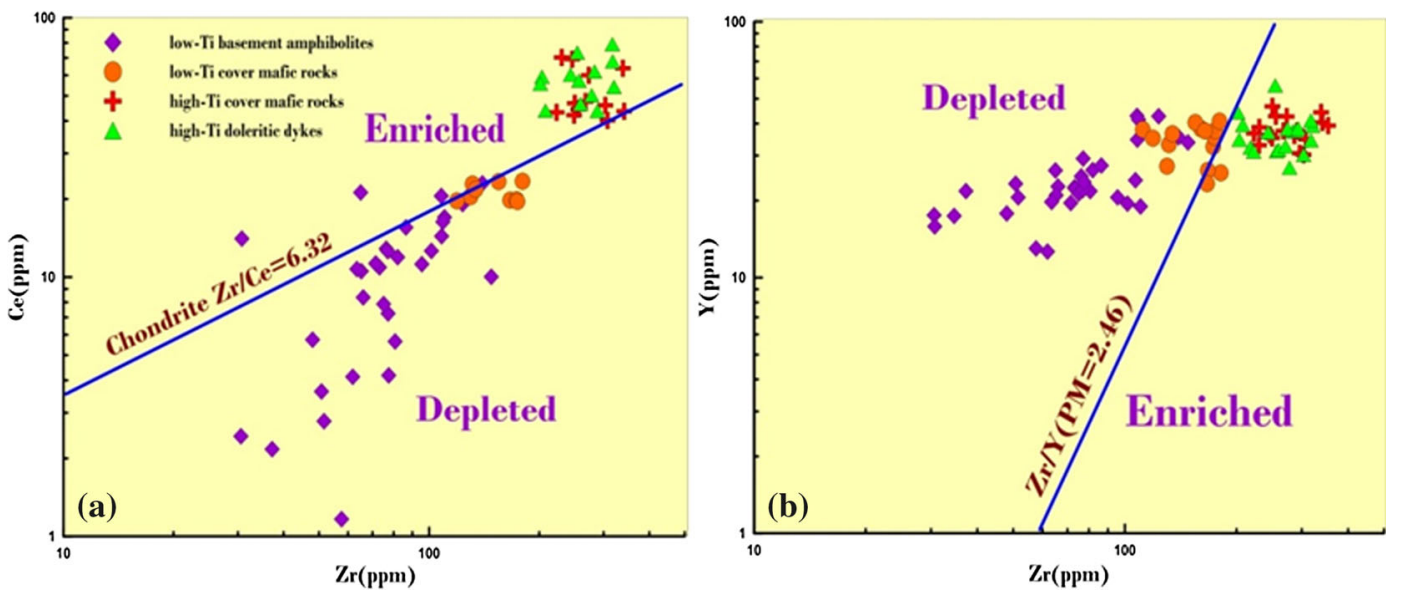

Figure 10. (a and b) Discrimination diagrams of Zr vs. Ce and Y and bivariate plot reflect the enriched and depleted source of the high- and low-Ti mafic samples.

of crustal material. Large variations in $\mathrm{Nb} / \mathrm{La}$ and $\mathrm{La} / \mathrm{Sm}$ ratios possibly reflect varying influence of the crustal material and also some LREELILE enrichment processes. Moreover, $\mathrm{Nb} / \mathrm{La}$ and $\mathrm{Nb} / \mathrm{Ce}$ ratios of the mafic rocks and dykes vary from 0.10 to 0.94 and from 0.08 to 0.50 , respectively, which are lower compared to the respective primitive mantle values of 1.02 and 0.4 , but not much different from the average crustal values of 0.69 and 0.33, respectively (Taylor and McLennan 1985). So, it becomes apparent that crustal contamination alone cannot produce lower ratios of $\mathrm{Nb} / \mathrm{La}$ and $\mathrm{Nb} / \mathrm{Ce}$. The observed negative $\mathrm{Sr}$ and $\mathrm{Eu}$ anomalies and geochemical characteristics of the Biabanak-Bafq district mafic rocks and dykes reflect enriched source characteristics.

\subsection{Tectonic settings of mafic rocks}

On the $\mathrm{MnO} * 10-\mathrm{TiO}_{2}-\mathrm{P}_{2} \mathrm{O}_{5} * 10$ (figure 11a) ternary tectono-magmatic diagram (after Mullen 1983), it becomes evident that the low-Ti base amphibolites, low- and high-Ti cover mafic rocks of Biabanak-Bafq district plot in distinct IAT, CAB, OIT and OIA fields, respectively. On the other hand, the majority of low-Ti basement amphibolites plot in the IAT and CAB field, the low-Ti cover mafic rocks fall in the IAT-OIT border and high-Ti alkaline mafic samples in the OIT and OIA fields. In the tectonic discrimination diagram Ti/1000 against V (ppm) (after Shervais 1982), the low-Ti basement samples plot in the arc-tholeiite basalts and low-Ti cover mafic rocks in the continental flood basalt (CFB), which occupy within the 10 to $20 \mathrm{Ti} / \mathrm{V}$ ratios (figure $11 \mathrm{~b}$ ).
Whereas the high-Ti cover mafic rocks as well as doleritic dykes plot in the oceanic island and alkali basalt field within the 50 to $100 \mathrm{Ti} / \mathrm{V}$ ratios. The high-Ti alkaline mafic samples show high ratios of $\mathrm{Ti} / \mathrm{V}(>20)$ within the range of typical OIB and continental tholeiites.

As discussed earlier, the high-Ti mafic rocks are part of the extensional tectono-magmatic event, which had affected in Biabank-Bafq district, these are consistent with the evolutionary history of the ANS (Stern et al. 1984; Stern and Voegeli 1987). The extensive Late Neoproterozoic low- to highTi cover mafic rocks of the Biabanak-Bafq district is comparable to the post-orogenic calc-alkaline (630-590 Ma) and alkaline (610-590 Ma) rocks of the north ANS. Both these magma types were emplaced between 610 and 590 Ma (Merrt 2003; Avigad and Gvirtzman 2009; Be'eri-Shlevin et al. 2009; Azer et al. 2010, 2012; Eyal et al. 2010; Azer 2013). It appears that these magmas might have formed during crustal thinning and extension (Be'eri-Shlevin et al. 2009; Beeri-Shlevi et al. 2010; Eyal et al. 2010). The negative Nb, P, and $\mathrm{Ti}$ anomaly suggests the involvement of titanomagnetite/rutile fractionation and/or influence of sub-continental lithosphere on the mantle-derived rocks (Tarney 1992; Dasgupta et al. 2013). Considering that the $\mathrm{Sm} / \mathrm{Yb}$ ratio is susceptible to the presence or absence of residual garnet in the source and also that $\mathrm{La} / \mathrm{Sm}$ and $\mathrm{Sm} / \mathrm{Yb}$ ratios are sensitive to the degree of partial melting (Neumann et al. 2014). The low-Ti basement amphibolites and low-Ti cover rocks reveal a generation of mafic magma from shallow garnet free source(s) (Huang et al. 2000). Also, a strong enrichment 

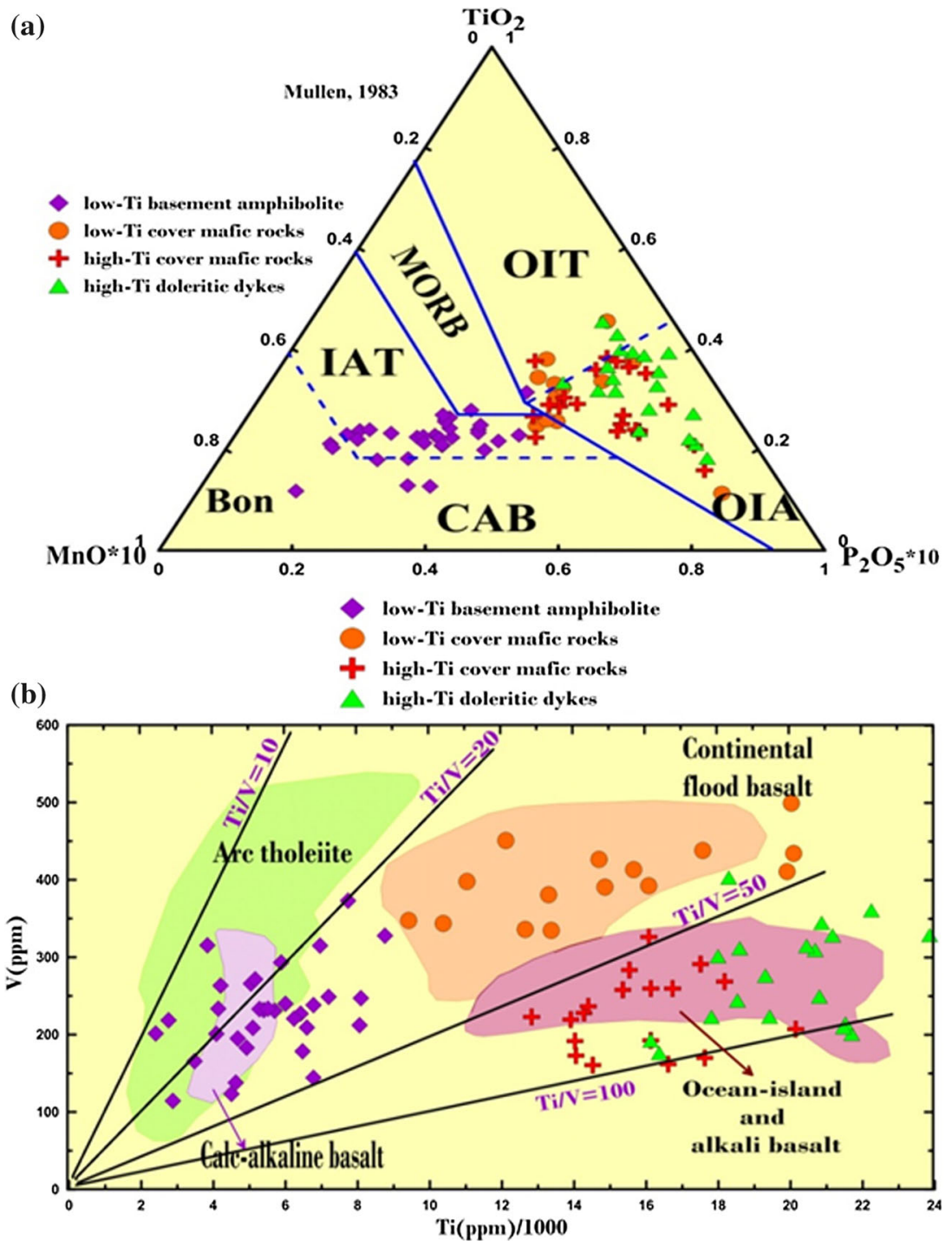

Figure 11. (a) $\mathrm{MnO}^{*} 10-\mathrm{TiO}_{2}-\mathrm{P}_{2} \mathrm{O}_{5} * 10$ ternary tectono-magmatic diagram (after Mullen 1983), indicating of plotting the low-Ti basement amphibolites in the island arc tholeiite (IAT) and the majority of high-Ti cover alkali mafic rocks as well as dolerites in the oceanic island arc (OIA) fields. Interestingly, a few samples of high-Ti followed by low-Ti cover mafic rocks and plot within the IAT and OIT fields close to border lines. (b) Ti/1000 vs. V (ppm) binary tectonic discrimination diagram (after Shervais 1982).

of LILE (Ba and Sr) coupled with enrichment of the incompatible elements $\mathrm{Zr}$ and $\mathrm{Ti}$ relative to $\mathrm{Y}$ and $\mathrm{Yb}$, leave little doubt that these high-Ti mafic rocks, as well as dolerite dykes, are the products of a smaller degree of partial melting. The post-collisional stage of tectono-magmatic evolution of the ANS commenced at $\sim 620 \mathrm{Ma}$, the transition from convergence to extension occurred at $\sim 600$ Ma (Jarrar et al. 1993; Stern 1994; Genna et al. 2002; Be'eri-Shlevin et al. 2009) that finally gave way to a stable craton and platform setting (Be'eri-Shlevin et al. 2009). The cover volcanic rocks vary from acid to basic in composition and include rhyolite-rhyodacite, tuff and keratophyre-spilitic lava that appear geochemically related. The mafic to ultramafic intrusive rocks, doleritic dykes indicate distinct $\mathrm{Fe}-\mathrm{Ti}$ rich basalts.

The resemblance among the EMII, OIBs and some basaltic rocks from island-arc settings, where sediment subduction and contamination of upper mantle wedge is strongly implicated (e.g., Banda and Antilles arcs; Hart 1985, 1988), suggest that a subduction-modified SCLM may be another potential EMII-like mantle reservoir. We propose therefore that the EMII component recognized in the cover mafic rocks of Biabanak-Bafq district may have been derived from an SCLM modified by the 


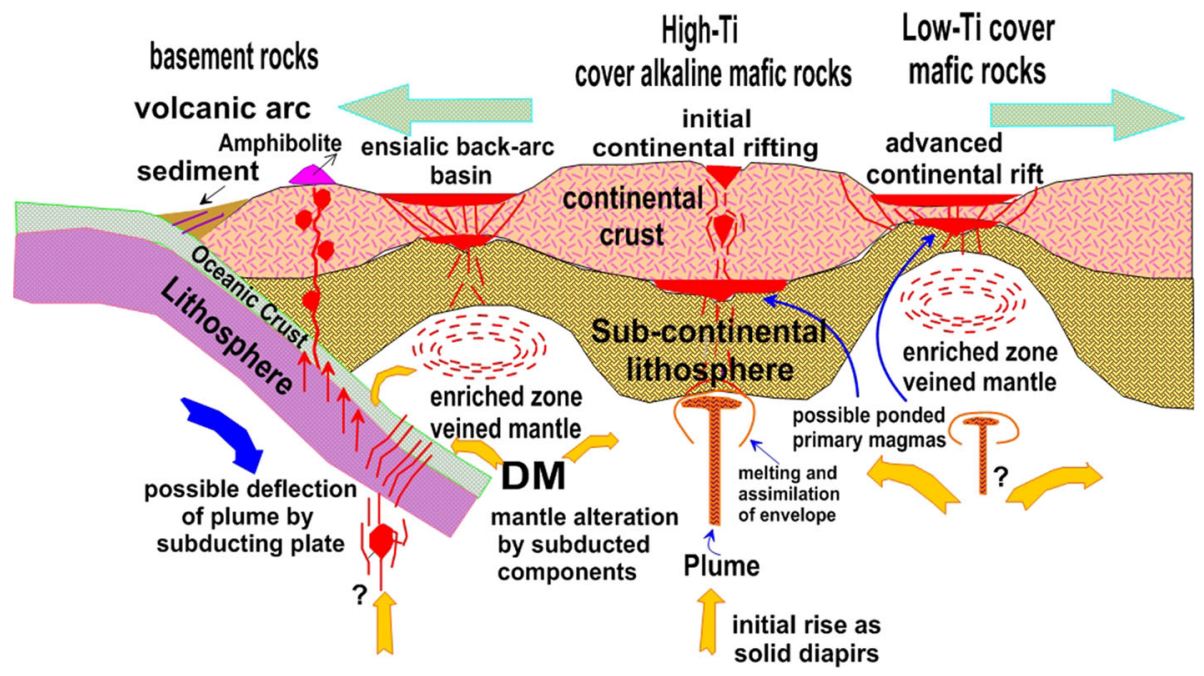

Figure 12. A hypothetical model for the magmatism of Proterozoic basement and cover rocks in the BiabanakBafq district.

addition of subduction-related metasomatic fluids during the Late Proterozoic. The partial melting for the high-Ti group probably occurred within the asthenosphere, with inputs from the SCLM in various proportions.

Studies of rift-related mafic dyke swarms associated with high-Ti mafic rocks are essential for the understanding generation of such extensive mafic magmatism and to identify asthenospheric upwelling (Ernst and Buchan 1997, 2001). There is general agreement that mafic magma experiences some degree of crustal contamination during ascent and/or residence in crustal magma chambers (Yu et al. 2015). Crustal contamination has been shown to be important in the petrogenesis of flood basalts (Devey and Cox 1987; Peng et al. 1994; Chesley and Ruiz 1998; Baker et al. 2000). On the other hand, a mantle source enriched in incompatible trace-elements, not influenced by a major crustal input, was postulated for some Proterozoic dyke swarms (Condie et al. 1987; Tarney and Weaver 1987; Boily and Ludden 1991) and other flood basalts (Molzahn et al. 1996). If a mantle derived geochemical signature can be demonstrated, it remains difficult to locate the mantle source, i.e., whether the magmas are predominantly derived from the sub-continental lithospheric mantle (SCLM) (e.g., Gallagher and Hawkesworth 1992; Turner et al. 1996), from an upwelling asthenospheric mantle (e.g., LeCheminant and Heaman 1989; Walker et al. 1997; Puchtel et al. 1999) or from a mixture of both (e.g., Ellam 1992; Gibson et al. 1995). Magmas of continental igneous provinces are generally large volumes of tholeiitic flood basalts with several geochemical features similar to that of ocean island basalts (OIB) providing evidence for an enriched mantle source (Eby 1985). Thus, like OIB, magmas from many continental igneous provinces are believed to reflect mantle melts associated with a mantle upwelling. As discussed earlier, the low-Ti cover mafic series correspond quite well with the range of variation seen in the Posht-e-Badam sequence, and could be feeders; the other type high-Ti series, has more alkalic characteristics (high $\mathrm{Nb} / \mathrm{Zr}$ ) and could represent rift volcanic, or tectonically accreted fragments of ocean islands (Ahmad and Tarney 1994). According to Ahmad and Tarney (1991), even though such geochemical features are generally assumed to indicate contamination of the magmas with a continental crust constituent, the evidence is strongly in favour of the compositional characteristics being inherited from their mantle source. These geochemical characteristics are possibly imposed upon the sub-continental lithosphere at the time of continent formation, but in the case of younger CFB suites, this may have been modified to a lesser extent by following additions of asthenospheric mantle material. Generation of the Biabanak-Bafq district cover, mafic volcanic rocks could be induced by upwelling asthenospheric mantle responding to regional extension and/or stress release (Cloetingh and Wortel 1985, 1986).

In the proposed model (figure 12), it is possible that there was an initial rifting between the eastern and western central Iran or otherwise between basement complexes in the west and cover rocks 
in the east, there may be extension/stretching of sub-continental lithosphere within the central Iran craton in turn produced highly attenuated crust/lithosphere. The sediments were deposited above this attenuated crust, followed by mafic intrusion before the stabilization of this craton. As the mafic magma ascent through thin/attenuated crust that was undergoing extension, they show lesser crustal contamination supporting the above observation. Therefore, the cover high-Ti alkali mafic-ultramafic magmatism formed within the intraplate continental rift tectonic environment setting. It is also possible that there was some activity undergoing during that time due to which crustal stretching initiated within the craton. It may be possible that there was a plume activity.

\section{Acknowledgements}

The authors are grateful to Prof. Arai of Kanazawa University for his comments and patient reviewing of the manuscript. The present state of the manuscript is entirely due to his help. The authors would like to acknowledge the support they received from Geological Survey of Iran during the collection of geological samples. They are also grateful to Director of GSI for permitting to carry out this work at University of Delhi. Thanks are also due to the reviewers for their constructive comments.

\section{References}

Ahmad T and Tarney J 1991 Geochemistry and petrogenesis of Garhwal volcanics: Implications for evolution of the NIndian lithosphere; Precamb. Res. 50(1-2) 69-88.

Ahmad T and Tarney J 1994 Geochemistry and petrogenesis of late Archean Aravalli volcanics, basement enclaves and granitoids, Rajasthan; Precamb. Res. 65(1-4) 1-23.

Ahmad T, Mukherjee P K and Trivedi J R 1999 Geochemistry of Precambrian mafic magmatic rocks of the western Himalaya, India: Petrogenetic and tectonic implications; Chem. Geol. 160(1-2) 103-119.

Alavi M 1991 Tectonic map of the Middle East: Tehran; Geological Survey of Iran, scale 1:5,000,000.

Alirezaei S and Hassanzadeh J 2012 Geochemistry and zircon geochronology of the Permian A-type Hasanrobat granite, Sanandaj-Sirjan belt: A new record of the Gondwana break-up in Iran; Lithos 151 122-134.

Avigad D and Gvirtzman Z 2009 Late Neoproterozoic rise and fall of the northern Arabian-Nubian Shield: The role of the lithospheric mantle deamination and subsequent thermal subsidence; Tectonophys. 477 217-228.

Azer M K, Stern R J and Kimura J I 2010 Origin of a Late Neoproterozoic $(605 \pm 13 \mathrm{Ma})$ intrusive carbonate-albitite complex in southern Sinai, Egypt; Int. J. Earth Sci. 99(2) 245-267.

Azer M K, Abu El-Ela F F and Ren M 2012 The petrogenesis of late Neoproterozoic mafic dyke like intrusion in south Sinai, Egypt; J. Asian Earth Sci. 54 91-109.

Azer M K 2013 Late Edicaran (605-580 Ma) post-collisional alkaline magmatism in the Arabian-Nubian Shield: A case study of Serbal ring-shaped intrusion, southern Sinai, Egypt; J. Asian Earth Sci. 77 203-223.

Baker J, MacPherson C G, Menzies M A, Thiriwall M F, Al-Kadal M and Mattey D P 2000 Resolving crustal and mantle contributions to continental flood volcanism, Yemen: Constraints from mineral oxygen isotope data; $J$. Petrol. 41(12) 1805-1820.

Be'eri-Shlevin Y, Katzir Y and Whitehouse M 2009 Postcollisional tectonomagmatic evolution in the northern Arabian-Nubian Shield: Time constraints from ion-probe U-Pb dating of zircon; J. Geol. Soc. 166 71-85.

Beeri-Shlevi Y, Katzir Y and Valley J W 2009 Crustal evolution and recycling in a juvenile contenint: Isotope ratio of zircon in the northern Arabian -Nubian Shield; Lithos 107 169-184.

Beeri-Shlevi Y, Katzir Y Blichert-Toft, Kleinhanns I C and Whiteehouse M $2010 \mathrm{Nd}$-Sr -Hf -O isotope provinciality in the northernmost Arabian -Nubian Shield: Implications for crustal evolution; Contrib. Mineral. Petrol. 160 181201.

Berberian M and King G C P 1981 Towards a paleogeography and tectonic evolution of Iran; Can. J. Earth Sci. 18(2) 210-265.

Bhattacharya S, Das P, Chaudhary A K and Saw A K 2010 Mafic granulite xenoliths in the Eastern Ghats belt: Implications for lower crustal processes in the south eastern Indian peninsula; Ind. J. Geol. 80 55-69.

Bhattacharya S, Das P, Chaudhary A K and Saw A K 2011 Mafic granulite xenoliths in the eastern Indian shield: Evidence for recycled continental crust in the Archean mantle; Lithosphere 3(2) 155-169.

Bickle M J 1986 Implications of melting for stabilisation of the lithosphere and heat loss in the Archaean; Earth Planet Sci. Lett. 80(3-4) 314-324.

Boily M and Ludden J N 1991 Trace element and Nd isotopic variations in Early Proterozoic dyke swarms emplaced in the vicinity of the Kapuskasing structural zone: Enriched mantle or assimilation and fractional crystallization process?; Can. J. Earth Sci. 28(1) 26-36.

Chesley J T and Ruiz J 1998 Crust-mantle interaction in large igneous provinces: Implications from the Re-Os isotope systematics of the Columbia River flood basalts; Earth Planet Sci. Lett. 154(1-4) 1-11.

Cloetingh S and Wortel R 1985 Regional stress field of the Indian Plate; Geophys. Res. Lett. 12(2) 77-80.

Cloetingh S and Wortel R 1986 Stress in the Indo-Australian Plate; Tectonophys. 132 49-67.

Condie K C, Bobnow D J and Card K D 1987 Geochemistry of Precambrian mafic dykes from the southern Superior Province; In: Mafic Dyke Swarms (eds) Halls H C and Fahrig W D, Geol. Assoc. Can. Spec. Papers 34 95-108.

Condie K C 1990a Geochemical characteristics of Precambrian basaltic greenstones; In: Early Precambrian basic magmatism (eds) Hall R P and Hughes D J, Blackie Publication, Glasgow, UK, pp. 40-55. 
Condie K C 1990b Growth and accretion of continental crust: inferences based on Laurentia; Chem. Geol. 83(3-4) 183194.

Cummins L E, Arthur J D and Ragland P C 1992 Classification and tectonic implications for early Mesozoic magma types of the circum-Atlantic; In: Eastern North American Mesozoic Magmatism (eds) Puffer J H and Ragland P C, Geol. Soc. Am. Spec. Paper 268 119-135.

Daliran F 2002 Kiruna-type iron oxide-apatite ores and apatitites of Bafq district, Iran, with an emphasis on the REE geochemistry of their apatite's; In: Hydrothermal iron oxide copper-gold and related deposits (ed.) Porter T M, PGC Publishing, Linden Park, South Australia, pp. 303-320.

Daliran F, Stosch H G and Williams P 2009 A review of the Early Cambrian magmatic and metasomatic events and their bearing on the genesis of the Fe oxide-REE apatite deposits (IOA) of the Bafq District, Iran; In: Smart science for exploration and mining (eds) Williams et al., Proceedings of the 10th Biennial SGA Meeting, Townsville, Australia, 17-20th August.

Daliran F, Stosch H G, Williams P, Jamali H and Dorri M B 2010 Early Cambrian iron oxide-apatite-REE (U) Deposits of the Bafq District, east-central Iran; In: Exploring for Iron oxide copper-gold deposits: Canada and Global analogues (eds) Corriveau L and Mumin H, Geol. Assoc. Can. Short Course Notes 20 143-155.

Dasgupta S, Bose S and Kaushik D 2013 Tectonic evolution of the Eastern Ghats Belt, India; Precamb. Res. 227 247258.

Davies J F, Grant R W E and Whitehead R E S 1979 Immobile trace elements and Archean volcanic stratigraphy in the Timmins mining area, Ontario; Can. J. Earth Sci. 16(2) 305-311.

Devey C V and Cox K J 1987 Relationship between crustal contamination and crystallization in continental flood basalt magmas with special reference to the Deccan traps of the Western Ghats, India; Earth Planet. Sci. Lett. 84(1) 59-68.

Drury S A 1983 The petrogenesis and tectonic setting of Archaean metavolcanics from Karnataka state, south India; Geochim. Cosmochim. Acta 47(2) 317329.

Eby N $1985 \mathrm{Sr}$ and $\mathrm{Pb}$ isotopes, $\mathrm{U}$ and $\mathrm{Th}$ chemistry of alkaline Montregian and White Mountain igneous provinces, eastern North America; Geochim. Cosmochim. Acta 49(5) 1143-1153.

Ellam R M 1992 Lithospheric thickness as a control on basalt geochemistry; Geology 20(2) 153-156.

Ernst R E and Buchan K L 1997 Layered mafic intrusions: A model for their feeder systems and relationship with giant dyke swarms and mantle plume centres; S. Afr. J. Geol. 100(4) 319-334.

Ernst R E and Buchan K L 1997 Giant radiating dyke swarms: Their use in identifying pre-Mesozoic large igneous provinces and mantle plumes; In: Large Igneous Provinces: Continental, Oceanic, and Planetary Volcanism (eds) Mahoney J and Coffin M, Geophys. Monograph Ser. Am. Geophys. Union 100 297-333.

Ernst R E and Buchan K L 2001 Large mafic magmatic events through time and links to mantle plume heads; In: Mantle plumes: Their identification through time (eds)
Ernst R E and Buchan K L, Geol. Soc. Am. Boulder CO, pp. $483-575$.

Eyal M, Livinovsky B, Jan B M and Katzir Y 2010 Origin and evolution of post-collisional Magmatism: Coeval Neoproterozoic calc-alkaline and alkaline suites of the Sinai peninsula; Chem. Geol. 269(3-4) 153-179.

Floyd P A 1993 Geochemical discrimination and petrogenesis of alkalic basalt sequences in part of the Ankara mélange, central Turkey; J. Geol. Soc. London 150 541-550.

Gallagher K and Hawkesworth C 1992 Dehydration melting and the generation of continental flood basalts; Nature 358 57-59.

Genna A, Nehlig P, Goff E L E, Guerrot C and Shanti M 2002 Proterozoic tectonism of Arabian Shield; Precamb. Res. 117(1-2) 21-40.

Gibson S A, Thompson R N, Leonardo O H, Dickin A P and Mitchell J G 1995 The Late Cretaceous impact of the Trinidad mantle plume: Evidence from large-volume, mafic, potassic magmatism in SE Brazil; J. Petrol. 36(1) 189-229.

Ghorbani M 2013 The economic geology of Iran: Mineral deposits and natural resources; Springer Geol. Springer Sci. Bus. Med. Dordrecht 45 569p, https://doi.org/10. 1007/978-94-007.

Greenough J D, Fryer B J and Robinson P T 1990 Geochemical effects of alteration on mafic rocks from Indian Ocean Site 706; In: Proceedings of the Ocean Drilling Program (eds) Duncan R A, Backman J and Peterson L C, Sci. Results 115 85-92.

Greenough J D, Dostal J and Greenough L M M 2007 Incompatible element ratios in French Polynesia basalts: Describing mantle component fingerprints; Austr. J. Earth Sci. 54(7) 947-958.

Haghipour A 1974 Etude géologique de la region de Biabanak Bafq (Iran Central); petrologie et tectonique du precambrien et de sa couverture, Ph.D. thesis, universite scientifique et medicale de Grenoble, France, 403p.

Haghipour A 1977 Geological Map of the Biabanak-Bafq Area; Geological Survey of Iran.

Hanson G N 1980 Rare earth elements in petrogenetic studies of igneous rocks; Ann. Rev. Earth Planet. Sci. $8371-$ 406.

Hassanzadeh J, Stockli D F, Horton B K, Axen G J, Stockli L D, Grove M, Schmitt A K and Walker J D 2008 $\mathrm{U}-\mathrm{Pb}$ zircon geochronology of late Neoproterozoic-Early Cambrian Granitoids in Iran: Implications for paleogeography, magmatism, and exhumation history of Iranian basement; Tectonophys. 451(1-4) 71-96.

Hart W K 1985 Chemical and isotopic evidence for mixing between depleted and enriched mantle, northwestern USA; Geochim. Cosmochim. Acta 49(1) 131-144.

Hart S R 1988 Heterogeneous mantle domains: Signatures, genesis and mixing chronologies; Earth Planet. Sci. Lett. 90(3) 273-296.

Hergt J M, Chappell B W, McCulloch M T, McDougall I and Chivas A R 1989 Geochemical and isotopic constraints on the origin of the Jurassic dolerites of Tasmania; J. Petrol. 30 841-883.

Hoffman P F 1991 Did the breakout of Laurentia turn Gondwana inside-out?; Science 252(5011) 1409-1412.

Horan M F, Hanson G N and Spencer K J 1987 Pb and $\mathrm{Nd}$ isotope and trace elements constraints on the origin 
of basic rocks in an early Proterozoic igneous complex, Minnesota; Precamb. Res. 37(4) 323-342.

Huang S, Pollack H N and Shen P Y 2000 Temperature trends over the past five centuries reconstructed from borehole temperatures; Nature 403 756-758.

Irvine T N and Barager W R A 1971 A guide to the chemical classification of the common volcanic rocks; Can. J. Earth Sci. 8(5) 523-548.

Jackson J and McKenzie D 1984 Active tectonics of the Alpine-Himalayan Belt between western Turkey and Pakistan; Geophys. J. Roy. Astron. Soc. 77 185-264.

Jarrar G, Wachendorf H and Zachmann D 1993 A PanAfrican alkaline pluton intruding the Saramuj conglomerate, south-west Jordan; Int. J. Earth Sci. 82(1) 121135.

Jensen L S 1976 A New Cation Plot for Classifying Subalkalic Volcanic Rocks; Ontario Division of Mine, Miscellaneous Paper 66, 22p.

Kröner A 1985 Ophiolites and the evolution of the tectonic boundaries in the late Proterozoic Arabian-Nubian Shield of northeast Africa and Arabia; Precamb. Res. 27(1-3) 277-300.

Kumar A and Ahmad T 2007 Geochemistry of mafic dykes in parts of Chhotanagpur Gneissic Complex: Petrogenetic and tectonic implications; Geochem. J. 41(3) 173186.

Longjam K C and Ahmad T 2012 Geochemical characterization and petrogenesis of Khairanagh volcanics: Implications for crustal evolution; Geol. J. 47(2-3) 130-143.

LeCheminant A N and Heaman L M 1989 Mackenzie igneous events, Canada: Middle Proterozoic hotspot magmatism associated with ocean opening; Earth Planet. Sci. Lett. 96(1-2) 38-48.

Merrt J G 2003 A synopsis of events related to the assembly of eastern Gondwana; Tectonophys. 362(1-4) 1-40.

Molzahn M, Reisberg L and Worner G 1996 Os, Sr, Nd, Pb, $\mathrm{O}$ isotope and trace element data from the Ferrar flood basalt, Antarctica: Evidence for an enriched subcontinental lithospheric source; Earth Planet. Sci. Lett. 144(3-4) 529-546.

Mullen E D 1983 MnO- $\mathrm{P}_{2} \mathrm{O}_{5}-\mathrm{TiO}_{2}$ : A minor element discriminant for basaltic rocks of oceanic environments and its implications for petrogenesis; Earth Planet. Sci. Lett. 62 53-62.

Nabavi M H 1976 An introduction to the Iranian geology; Geological Survey of Iran, 110p. (in Persian).

Nadimi A 2007 Evolution of the central Iranian basement; Gondwana Res. 12(3) 324-333.

Nelson S T and Davidson J P 1993 Interactions between mantle derived magmas with mafic crust, Henry mountains, Utah; J. Geophys. Res. 98(B2) 1837-1852, https:// doi.org/10.1029/92JB02689.

Nesbitt R W, Sun S S and Purivs A C 1979 Komatiites: Geochemistry and genesis; Can. Mineral. 17 165-186.

Neumann W, Breuer D and Spohn T 2014 Differentiation of Vesta: Implications for a shallow magma ocean; Earth Planet. Sci. Lett. 395 267-280.

Pearce J A 1996 A user's guide to basalt discrimination diagrams; In: Trace element geochemistry of volcanic rocks: Applications for massive sulphide exploration (eds) Bailes A H, Christiansen E H, Galley A G et al., Short Course Notes, Geol. Assoc. Can. 12 79-113.
Peng Z X, Mahoney J J, Hooper P R, and Beane J 1994 A role for lower continental crust in flood basalt genesis? Isotopic and incompatible element study of the lower six formations of the western Deccan Traps; Geochim. Cosmochim. Acta 58(1) 267-288.

Pollard P J, Millburn D, Taylor R G and Cuff C 1983 Mineralogical and textural modifications in granites associated with mineralization, Herberton-Mt Garnet Tinfield, Queensland; Geological Society of Australia Queensland Division, pp. 413-430.

Puchtel I S, Brugmann G E and Hofmann A W 1999 Precise $\mathrm{Re}-\mathrm{Os}$ mineral isochron and $\mathrm{Pb}-\mathrm{Nd}-\mathrm{Os}$ isotope systematics of a mafic-ultramafic sill in the $2.0 \mathrm{Ga}$ Onega plateau (Baltic Shield); Earth Planet. Sci. Lett. 170(4) 447461.

Ramezani J and Tucker R D 2003 The Saghand region, Central Iran: U-Pb geochronology, petrogenesis and implications for Gondwana tectonics; Am. J. Sci. 303(7) 622-665.

Rollinson H 1993 Using Geochemical Data: Evaluation, Presentation, Interpretation; Longman, London, 352p.

Samani B 1988 Metallogeny of the Precambrian in Iran; Precamb. Res. 39(1-2) 85-106.

Schmidt D L, Hadley D G and Stoeser D B 1978 Late Proterozoic crustal history in southern Najd province, Saudi Arabia (abstract); Precamb. Res. 6 A35.

Shervais J W 1982 Ti-V plots and petrogenesis of modern and ophiolitic lavas; Earth Planet. Sci. Lett. 59(1) 101118.

Sillitoe R H 1979 Metallogenic consequences of late Neoproterozoic suturing in Arabia, Egypt, Sudan and Iran; In: Evolution and mineralization of Arabian-Nubian shield (volume 1) (ed.) Tahoun S A, Instit. Appl. Geol., Pergamon Press Ltd., Oxford 3 110-120.

Stern R J 1994 Arc assembly and continental collision in the Neoproterozoic East African Orogeny: Implications for the consolidation of Gondwana land; Ann. Rev. Earth Planet. Sci. 22 319-351.

Stern R J and Voegeli D A 1987 Geochemistry, geochronology, and petrogenesis of a late Precambrian ( $590 \mathrm{Ma})$ composite dike from the northeastern desert of Egypt; Geo. Rundschau. 76 325-341.

Stern R J, Gottfried D and Hedge C E 1984 Late Precambrian rifting and crustal evolution in the Northeastern Desert of Egypt; Geology 12 168-171.

Stöcklin J, Ruttner A and Nabavi M 1964 New data on the lower Paleozoic and Precambrian of North Iran; Geol. Surv. Iran $129 \mathrm{p}$.

Stöcklin J 1968 Structural history and tectonics of Iran: A review; Am. Assoc. Petrol. Geol. Bull. 52 1229-1258.

Stöcklin J 1974 Possible Ancient Continental Margins in Iran; In: The Geology of Continental Margins (eds) Burke C A and Drake C L, Springer Verlag, New York, pp. 873887.

Stöcklin J, Eftekharnezhad J and Hushmandzadeh A 1972 Central Lut reconnaissance, East Iran; Geol. Surv. Iran 22 62p.

Sun S S and Nesbitt R W 1977 Chemical heterogeneity of the Archean mantle composition of the bulk earth and mantle evolution; Earth Planet. Sci. Lett. 35(3) 429-448.

Sun S S and McDonough W F 1989 Chemical and isotopic systematics of oceanic basalts: Implications for mantle 
composition and processes; In: Magmatism in the Ocean Basins (eds) Saunders A D and Norry M J, Geol. Soc. London Spec. Publ. 42 313-345.

Tarney J, Wood D A, Varet J, Saunders A D and Cann J R 1979 Nature of mantle heterogeneity in the North Atlantic: evidence from Leg 49 Basalts; In: Results of Deep Sea Drilling in the Atlantic (eds) Talwani M, Harrison C G and Hayes D E, Maurice Ewing Series, Am. Geophys. Union 2 285-301.

Tarney J and Weaver B L 1987 Mineralogy, petrology and geochemistry of the Scourie dykes: Petrogenesis and crystallization processes in dykes intruded at depth; In: Evolution of the Lewisian and Comparable Precambrian High Grade Terrains (eds) Park R G and Tarney J, Geol. Soc. Spec. Publ. 27 217-233.

Tarney J 1992 Geochemistry and significance of mafic dyke swarms in the Proterozoic; In: Proterozoic Crustal Evolution: Developments in Precambrian Geology (ed.) Condie K C, Elsevier Amst. 10 151-179.

Taylor S R and McLennan S M 1985 The continental crust: Its composition and evolution, Blackwell Scientific Publication, Oxford, 312p.

Taylor R G and Pollard P J 1988 Pervasive hydrothermal alteration in tin-bearing granites and implications for the evolution of ore-heating magmatic fluids; In: Recent advances in the geology of granite-related mineral deposits, Quebec (eds) Taylor R P and Strong D F, Can. Instit. Mining Metallurgy, pp. 86-95.
Turner S, Hawkesworth C, Gallagher K, Peate D and Mantovani M 1996 Mantle plumes, flood basalts, and thermal models for melt generation beneath continents: Assessment of a conductive heating model and application to the Paraná; J. Geophys. Res. 101(B5) 11,503-11,518.

Verdel C, Wernicke B P, Ramezani J, Hassanzadeh J, Renne P R and Spell T R 2007 Geology and thermochronology of Tertiary Cordilleran-style metamorphic core complexes in the Saghand region of central Iran; Geol. Soc. Am. Bull. 119(7/8) 961-977.

Walker R J, Morgan J W, Beary E S, Smoliar M I, Czamanske G K and Horan M F 1997 Applications of the ${ }^{190} \mathrm{Pt}-{ }^{186} \mathrm{OS}$ isotope system to geochemistry and cosmochemistry; Geochim. Cosmochim. Acta 61(22) 47994808.

White R S and McKenzie D 1989 Magmatism at rift zones: the generation of volcanic continental margins and flood basalts; J. Geophys. Res. 94(B6) 7685-7729.

Whitney D L and Evans B W 2010 Abbreviations for names of rock-forming minerals; Am. Mineral. 95 185-187.

Winchester J A and Floyd P A 1977 Geochemical discrimination of different magma series and their differentiation products using immobile elements; Chem. Geol. 20325 344.

Yu X, Lee C A, Chen L H and Zeng G 2015 Magmatic recharge in continental flood basalts: Insights from the Chifeng igneous province in Inner Mongolia; Geochem. Geophys. Geosyst. 16 2082-2096. 